College of Business
and Public Policy
UNIVERSITY of ALASKA ANCHORAGE
Department of Economics Working Paper
WP 2018-07
July 2018

UAA DEPARTMENT OF ECONOMICS

3211 Providence Drive

Rasmuson Hall 302

Anchorage, AK 99508

http://econpapers.uaa.alaska.edu/ 
Managing and Defending the Commons: Experimental Evidence from TURFs in Chile

Carlos A. Chávez

Facultad de Economía y Negocios

Universidad de Talca and

Interdisciplinary Center for Aquaculture Research (INCAR)

James J. Murphy

Department of Economics \& Public Policy

University of Alaska Anchorage

John K. Stranlund

Department of Resource Economics

University of Massachusetts-Amherst

Acknowledgements: We gratefully acknowledge financial support for this research from Conicyt-Chile, under project Fondecyt Regular No. 1140502. Chávez also gratefully acknowledges additional partial funding for this research provided by INCAR through CONICYT/FONDAP/15110027. Stranlund acknowledges partial funding by the USDA/NIFA, Massachusetts Experiment Station Project No. MAS00453. 


\title{
Managing and Defending the Commons: Experimental Evidence from TURFs in Chile
}

\begin{abstract}
This work presents the results of framed field experiments designed to study the joint problem of managing harvests from a common pool resource and protecting the resource from poaching. The experiments were conducted both in the field with TURF users and in the lab with university students. Our study has two objectives. First, we designed our experiments to study the effects of poaching on the ability of common pool resource users to coordinate their harvests when encroachment by outsiders is unrestricted and when the government provides weak enforcement. Second, we examine the ability of common pool resource users to simultaneously coordinate their harvests and investments in monitoring to deter poaching with and without government assistance in monitoring. Weak external monitoring that was predicted to have no effect actually led to significantly lower poaching relative to unrestricted poaching. However, neither giving sole responsibility for monitoring to resource users nor combining user and government monitoring affected poaching levels much. Our results suggest that users of a common pool resource may have difficulties coordinating their efforts to deter poachers, even with help from government authorities. We find no important qualitative differences in the behavior of TURF users and university students.
\end{abstract}

Key Words: Common pool resources; economic experiments; enforcement; field experiments; poachers; territorial use rights fisheries.

JEL Codes: C90, K42, Q22

\section{Introduction}

Territorial use rights in fisheries (TURFs) are a fisheries management approach that allocate exclusive harvesting rights in a particular geographical location to a specific group of users. Solving the open access problem that often leads to over-exploited fisheries can allow members of a TURF to coordinate their harvest decisions to maximize the value of their resource stocks (Charles 2002, Christy 1982, Wilen et al. 2012). However, TURFs are prone to poaching from outsiders and hence, must be defended from outside encroachment (Chávez et al. 2010, Gelcich et al 2009, Gelcich et al. 2017). Often, enforcing access to a TURF is done by a combination of TURF members' efforts and the government. Therefore, members of a TURF have to confront the difficult problem of simultaneously managing their use of the resource and defending it against encroachment, given the enforcement efforts of the government. This coordination challenge is the problem we investigate in this paper. We do so with a series of economic experiments in the field with participants of the TURF system that regulates near-shore fishing along the coast of Chile, as well as in the lab with Chilean university students. 
Our experiments were framed as the harvest of a valuable benthic mollusc called loco or Chilean abalone. ${ }^{1}$ Two groups of three individuals harvested from two independent stocks of locos. In the paper we refer to the two groups as insiders and outsiders, however these terms were not used in the experiments. The insiders were able to communicate with each other, but not with the outsiders. The outsiders could not communicate with each other or with the insiders. In our Baseline treatment, the groups harvested from their own independent stocks of locos. In the other four treatments, the outsiders could poach from the insiders' stock, but insiders could not poach the outsiders' locos. In one of these treatments, poaching was unchecked by monitoring and sanctions. For the remaining three treatments we considered different monitoring conditions, given a fixed per unit sanction for poaching. One of these treatments featured an exogenous monitoring probability that was not high enough to lift the expected marginal sanction above the value of poaching a loco. This treatment allowed us to investigate the effects of weak external monitoring on poaching and the ability of the insiders to coordinate their harvests. In another enforcement treatment, the insiders made independent decisions to invest in collective monitoring to detect poaching. Of course, these investments were a second-order public good and hence, insiders may under-provide monitoring resources. However, as a group they always had the incentive to invest enough in monitoring to deter the outsiders. Whether they were able to do so is one of the main questions of this research. The final enforcement treatment allowed for a combination of external monitoring and insider investments in monitoring. Doing so lets us consider whether co-enforcement of TURF boundaries can produce more effective deterrence.

Our work contributes to the literature that uses economic experiments to investigate selfgovernance and co-management of common pool resources (see, for example, Ostrom 1990, Ostrom and Walker 1991, and Carlsson and Berkes 2005, among many others). More specifically, our work contributes to the subset of that research that uses framed field (Harrison and List 2004), or lab-in-the-field, experiments to examine features of the co-management of common pool resource use in the developing world with subjects whose livelihoods depend on the exploitation of local natural resources. ${ }^{2}$ An early example of this literature is from Cárdenas

\footnotetext{
1 The word loco comes from the indigenous Mapuche people.

${ }^{2}$ The motivation for conducting framed field experiments is that this approach recognizes that the way in which participants understand and approach economic experiments may be influenced by factors from their life experiences and the context in which the game is presented (Cárdenas and Ostrom 2004; Harrison and List 2004).
} 
et al. (2000) who conducted experiments in several rural areas of Colombia and found that a weakly enforced standard did not lead to more efficient choices because it appeared to crowd-out other-regarding preferences. ${ }^{3}$ Vollan (2008) investigated the conditions under which crowdingout emerges with framed field experiments conducted with communal farmers in Namibia and South Africa. Neither Cárdenas et al. (2000) nor Vollan (2008) allowed subjects to communicate with each other when they faced an external regulation. ${ }^{4}$ However, it is well-established that simple communication among all users within a group results in lower harvests from a common pool resource and higher payoffs (Ostrom and Walker 1991, Ostrom 2006). Accordingly, Vélez et al. (2010) tested whether there was a complementary relationship between communication and external regulation by conducting framed field experiments in several regions of Colombia. They found evidence of a complementary effect in some instances, but not all.

While there is an extensive literature on cooperation with both external and internal enforcement within groups, there has not been much research on the protection of common pool resources from encroachment by outsiders. ${ }^{5}$ With a set of laboratory experiments, Schmitt et al. (2000) found that limiting communication to a subset of harvesters made cooperation much more difficult. This suggests that communication alone is not effective at coordinating harvests when there are outsiders, like poachers, exploiting the same resource.

Crucially, Schmitt et al. (2000) did not restrict access to the common pool resource by outsiders. That is, there was no monitoring or sanctioning of outsiders either by an external authority or by the insiders themselves. With laboratory experiments, De Geest et al. (2017) took up the issue of whether common pool resource users could simultaneously coordinate their harvests and defend the resource from outsider encroachment. Theirs is the only other paper of which we are aware that uses economic experiments to investigate the problem of enforcing outsider access to common pool resources. In their paper, members of an insider group could monitor and sanction each other as well as communicate with each other. Thus, they had

\footnotetext{
${ }^{3}$ However, Abatayo and Lynham (2016) argue that this result is due to confounds present in the design of Cárdenas et al. (2000). With a set of laboratory experiments designed to remove these confounds, Abatayo and Lynham found that weakly enforced external regulations did not crowd out other-regarding preferences.

${ }^{4}$ A similar design is used by Gelcich et al. (2013) who, like us, conducted experiments with artisanal fishers on the Chilean coast to examine the co-management of common pool resources.

${ }^{5}$ The large literature that uses economic experiments to investigate mutual monitoring and sanctioning within groups to promote more cooperative choices includes Yamagishi $(1986,1988)$, Ostrom et al. (1992), and Fehr and Gächter (2000). Bell et al. (1989) investigate the ability of a group of common pool resource users to discourage stealing within the group. See DeAngelo et al. (2017) for a novel empirical application of co-enforcement of rules with an external authority and the references therein for additional examples of co-enforcement.
} 
multiple instruments for coordinating their choices. In addition, a group of outsiders could poach from the resource and the insiders could sanction any outsider they managed to observe poaching. The main result of this set of experiments is that insiders could not deter the outsiders, even when they observed their behavior perfectly, because they did not impose high enough sanctions and because they did not sanction lower levels of poaching.

Our study differs from De Geest et al. (2017) in several ways. One difference is that insiders in De Geest et al. could directly sanction outsiders, given exogenous differences in their ability to observe poaching across treatments. In contrast, we examine different ways to provide monitoring for poaching, given a fixed sanction. This is closer to the Chilean TURF experience where TURF members can monitor access to their management area, but they cannot legally sanction encroachment. Another difference between our work and De Geest et al. is that there was no role for a government authority in their experiments. In Chile, multiple government agencies are responsible for enforcing TURF access, and the possibility of co-management in terms of deterring poaching is one of the main motivations for our work. ${ }^{6}$ Moreover, the experiments of De Geest et al. were conventional laboratory experiments with a neutral frame conducted with university students, while our experiments were framed as harvesting an important resource for Chilean nearshore fisheries. The experiments were conducted with members of Chilean TURFs and replicated with university students. This replication is particularly useful in light of the ongoing discussions about replication in science (Camerer et al. 2016, Dreber et al. 2015). Finally, De Geest et al. implemented a repeated static game of harvests from a common pool resource, while our underlying game was dynamic with two stocks of the resource each with stock-dependent growth. Our approach allows us to consider how poaching and its potential deterrence affects the sustainability of resource stocks in a way that De Geest et al. could not.

Our efforts produce important new results about the joint defense of common pool resources by users of the resource and a government authority. In our Baseline treatment we find a strong tendency for the insiders to sustain their resource stocks throughout the entire length of the sessions. However, unrestricted poaching weakened the ability of the insiders, both TURF

\footnotetext{
${ }^{6}$ The general framework for regulating artisanal fisheries in Chile is provided by the General Fisheries and Aquaculture Law enacted in 1991. According to this framework, monitoring and enforcement of artisanal fisheries regulations is the responsibility of the National Fisheries Service, the Chilean Navy and the local police forces (Carabineros). In practice, the National Fisheries Service does most government monitoring and enforcement.
} 
members and students, to sustain their resource stocks and to coordinate their harvests. While the insiders were able to sustain their stocks for longer than the non-cooperative Nash equilibrium prediction, their cumulative harvests and payoffs were not significantly different from Nash equilibrium levels.

Poaching was significantly lower under our enforcement treatments. Weak external monitoring that was predicted to have no effect on outsider choices actually led to significantly lower poaching for TURF users. Making monitoring the sole responsibility of the insiders did not change outsider poaching and insider harvests and payoffs compared to weak external enforcement. While the insiders had the incentive to jointly invest enough in monitoring to make poaching inefficient, they could not coordinate their monitoring investments well enough to mount a successful deterrent. However, they did make positive investments in monitoring that resulted in partial deterrence of poaching. Surprisingly, while we expected that combining weak external monitoring with insider investments in monitoring would have allowed the insiders to better deter the outsiders, poaching was not significantly different under this condition than under weak external monitoring alone or under insider monitoring alone. Average poaching gains for outsiders in this treatment were negative for both TURF members and students, leading us to question whether poaching would persist in the field under these conditions. Nevertheless, our results suggest that users of a common pool resource are likely to struggle to coordinate their efforts to deter outsiders, even with help from the government.

The rest of the paper proceeds in the following way. In the next section, we provide a brief description of the Chilean TURF system for nearshore resources that motivates and frames our study. In section 3, we describe the design of our experiments, the theoretical benchmarks for each treatment, and the procedures we used to implement our experiments. We report the results of our experiments in section 4 , and conclude in section 5 .

\section{TURFs in Chile}

Chilean abalone or loco (Concholepas concholepas) is one of the main benthic resources exploited by artisanal fisheries along the Chilean coast. In the late 1970s, Chile's abalone fishery was opened to international export markets, leading to a substantial increase in harvests. At the time the fishery was characterized by open access. Predictably, increased harvests for export led to severe stock depletion and increasingly shorter seasons. Eventually, the fishery was closed 
nationwide in 1989 (Bustamante and Castilla 1987, Bustos et al. 1991, Gonzalez et al. 2006). The fishery re-opened in 1992 under an individual quota system, which subdivided a total allowable catch among individual divers. Similar species-specific harvest quota programs had been successful in New Zealand and Iceland. However, the Chilean individual quota program was largely viewed as a failure, mainly because of poor stock assessments and the lack of enforcement (Leiva and Castilla 2002, Gonzalez et al. 2006).

In 1997, Chile implemented the Management and Exploitation Areas of Benthic Resources (MEABR) management system, which assigned local artisanal fishing organizations exclusive use rights of all the benthic resources from specific geographic areas located within five nautical miles of the coast or inland waters. The MEABR regime was intended to promote conservation and rationalize the use of benthic resources, as well as to facilitate cooperation between artisanal fishing associations and the National Fisheries and Aquaculture Service (SERNAPESCA, by its Spanish acronym). This regime was expected to become a durable management system that would enhance artisanal economic activity by creating rights to natural shoals of benthic resources (Subsecretaría de Pesca,1995).

The MEABR management system has the potential to overcome some of the problems that led to the failure of the earlier species-specific individual quota program. Under the MEABR, local TURFs are responsible for developing a management plan at their own expense, including annual stock assessments to determine sustainable harvest levels, and defining the rules that govern how the resources would be harvested. By shifting much of the costs and responsibilities for managing resources to the local organizations that would also reap the benefits of these efforts, the MEABR system better aligns the incentives for efficient resource management. However, this approach faces important challenges. Success of the MEABR system depends upon the ability of the TURFs to self-govern and overcome collective action problems. Although there is substantial variation in how each TURF is managed, most have been able to successfully implement a rationalized harvest plan that defines access privileges, sanctions for noncompliance by group members, responsibilities for policing borders, and other duties associated with managing the TURF (Wilen et al. 2012).

Similar programs have been used successfully for generations in the South Pacific (Wilen et al. 2012) and Japan (Cancino et al. 2007), but the Chilean MEABR program was established in the absence of any prior tradition and is still evolving. Some, but not all, of the essential 
elements usually observed in long-enduring commons (Ostrom 1990) are present in many of the Chilean TURFs, but their long-run success will depend upon whether the remaining hurdles can be overcome.

Of particular concern is illegal poaching (Aburto et al. 2013, Moreno and Revenga 2014). Surveys of TURF fishers and leaders in central Chile reveal that they believe that poaching and the difficulties of deterring poaching are key problems in the management of TURFs. Moreover, TURF members and their leaders desire greater support from government authorities to deter poaching (Gelcich et al. 2009, Gelcich et al. 2017). Lack of government support in monitoring and sanctioning may diminish the motivation of TURF members to monitor their resource to deter poaching (Davis et al. 2017). However, local TURFs have tried to protect their territories by patrolling and chasing intruders out of their management areas (Chávez et al. 2010). At times, these incidents have escalated to violent encounters, including murders.

In response to concerns about the lack of government support, in 2014 the Chilean National Service of Technical Cooperation (SERCOTEC by its Spanish acronym) together with the Regional Government of Los Lagos region in southern Chile launched a program to help local TURFs design, implement, and operate monitoring systems to help reduce poaching in their management areas. This program targeted an area of Los Lagos region with a high concentration of TURFs and where illegal activities and an increasing number of violent incidents between poachers and TURF members have been reported in recent years. About 30 TURFs have received subsidies from the government. The funds have been invested in monitoring and patrolling equipment, including fast modern patrol boats, engines, lights for night monitoring at sea, and radio equipment to facilitate communication between TURF members and the authorities.

\section{Experimental Design, Predictions, and Procedures}

Our study is motivated by the Chilean TURF experience with respect to deterring poaching. In particular, we are concerned with the effects of poaching on the ability of a group of common pool resource users to coordinate their harvests when encroachment by outsiders is unrestricted, and when the government provides weak enforcement against encroachment. Moreover, we are concerned with the ability of common pool resource users to simultaneously coordinate their harvests and investments in monitoring to deter poaching, with and without government 
assistance in monitoring for poaching. We conducted a series of lab-in-the-field experiments with members of TURF programs in south-central Chile. As a robustness check, we replicated these experiments with students from a local university.

\subsection{Experimental design, treatments, and theoretical benchmarks}

The experiments were framed as managing the harvesting (using the Spanish word extracción) of Chilean abalone, or loco, from two independent zones or stocks of locos. Each session consisted of a maximum of two groups of six individuals. Assignment to one of the two groups was random. Within each six-person group, subjects were randomly divided into two groups of three participants, the blue group and the yellow group. We used a partner's design in which the group composition did not change, and an individual's assignment to the blue or yellow group was fixed for the entire experiment. Subjects were told that the blue locos belonged (using the Spanish word pertenecen) to the blue group and that the yellow locos belonged to the yellow group. Throughout this paper, we refer to the 'insiders' (blue group) and the 'outsiders' (yellow group), although we avoided any reference to insiders and outsiders in the experiment.

The basic structure of how the resource functioned was adapted from Cárdenas et al. (2013). In both zones, the resource evolved over time according to a stock dependent growth function and aggregate harvests. In each zone the stock size grew by one loco for every complete set of 10 locos that remained in the zone at the end of the previous period. Growth was limited to a maximum stock size, which was 70 locos in the blue zone and 45 locos in the yellow zone. ${ }^{7}$ At the start of period $t=1$, the initial biomass in each zone was equal to the maximum stock size. Each session lasted a maximum of 10 periods, but each zone could be closed earlier if its stock fell below a critical value, which was 30 locos in the blue zone and 15 locos in the yellow zone. Any locos remaining at the end of period 10 had no value.

Harvest capacity for each participant was five units per period. The price of a harvested loco, regardless of color, was a constant 500 Chilean pesos. The critical values were chosen such that individuals could harvest at full capacity in the last period before the zone was closed. ${ }^{8}$ The critical level in the blue zone was 30 because in most of our treatments both insiders and outsiders could harvest in the blue zone. The critical level was 15 in the yellow zone because

\footnotetext{
${ }^{7}$ The different stock sizes in the blue and yellow zones were chosen to reflect that members of a TURF are generally in an advantaged position relative to outsiders.

${ }^{8}$ Otherwise, we would need an ad hoc allocation rule if the aggregate harvest exceeded the stock size.
} 
only the outsiders could harvest in that zone. Throughout the paper, when we refer to a zone or resource being depleted we mean that the resource stock fell below its critical value. A closed zone could not reopen later. It was possible for one zone to close while the other remained open.

We conducted five treatments as described below. In all treatments, to parallel the communication that occurs within a TURF, the insiders were able to communicate with each other for three minutes at the start of each round, but they could not communicate with the outsiders. Given the field context, it would have been unrealistic to restrict communication among members of a TURF. The outsiders usually operate independently and do not communicate to coordinate their actions. Therefore, in all treatments, the outsiders were unable to communicate with each other or with the insiders. Except for the Baseline treatment, the outsiders could poach from the blue zone. The insiders could not poach from the yellow zone in any of the five treatments. ${ }^{9}$ Poaching could be sanctioned in three of the four treatments in which poaching was allowed. If an outsider was caught poaching from the blue zone in these treatments, he or she was sanctioned with a constant per unit fine. In one of these three enforcement treatments, there was an exogenous probability of observing an outsider's choices. This monitoring was provided by an outside authority. In another enforcement treatment, the insiders could invest in increasing the probability of observing an outsider. The last enforcement treatment is a combination of the other two, such that both the resource users and the external authority provide monitoring.

In Table 1, we present theoretical benchmark equilibria for each treatment. ${ }^{10} \mathrm{We}$ present symmetric individual harvests within zones, individual yellow (outsider) poaching in the blue (insider) zone except in the Baseline treatment, terminal periods in the blue (insider) and yellow (outsider) zone, individual monitoring costs when insiders could invest in monitoring the outsiders, and individual payoffs (or expected payoffs). All benchmarks assume either cooperative or non-cooperative harvests, by which we mean that harvesters in a zone are able to coordinate their harvest strategies to maximize the joint payoffs of the group (cooperative), or they are not able to coordinate their harvest choices so they choose pure Nash strategies (non-

\footnotetext{
${ }^{9}$ In the instructions, participants were told, "Although the blue locos belong to the blue participants, it is possible for yellow participants to harvest blue locos. Blue participants cannot harvest yellow locos."

${ }^{10}$ We do not provide the derivations of these outcomes, but they are available in section 1 of the online Appendix at: <insert URL>.
} 
cooperative). ${ }^{11}$ In the treatments in which the insiders can invest in monitoring the outsiders, the insiders can coordinate, or fail to coordinate, their choices in two domains. Our theoretical benchmarks account for the possibilities that the insiders are able to coordinate both their harvest and monitoring choices, that they are able to cooperate in one domain but not the other, and that they fail to coordinate both harvests and investments in monitoring.

\section{$<$ INSERT TABLE $1>$}

T1. Baseline: In this treatment the blue group could only harvest blue locos and the yellow group could only harvest yellow locos. It was not possible for the outsiders to poach from the blue zone. Thus, this was a simple linear dynamic common pool resource game with two independent groups and resource stocks. The groups were distinguished from each other in that the insiders could communicate with each other at the start of each round while the outsiders could not, and the insiders began with a larger initial (and maximum) stock size. This treatment established a baseline level of cooperation and stock dynamics in the absence of poaching or enforcement.

If the subjects were able to coordinate their harvests to maximize their group payoff, then the best cooperative strategy would be to draw the resource down to the level that maximizes sustained group harvests, maintain this level for a number of periods, and then harvest at capacity in the remaining periods so that the stock falls below the critical stock size in period 10. In contrast, if the harvesters cannot coordinate their harvests, then there is no incentive for any individual to limit his or her harvest. Therefore, in both zones, individuals would harvest to capacity in every period until the stock falls below the critical stock level. From Table 1, this would occur in four periods for the insiders in the blue zone and three periods for the outsiders in the yellow zone. Using the equilibrium payoffs in Table 1, if insiders were able to coordinate their harvest they could earn $66.7 \%$ more than if they did not coordinate their harvests. Similarly,

\footnotetext{
${ }^{11}$ Except for the Baseline treatment, we do not present benchmarks involving cooperative harvest strategies by the outsiders. We do this for two reasons. First, our primary focus is on the ability of the insiders to coordinate their harvest and monitoring choices under the different monitoring conditions and we do not want to distract from this. Second, we do not give the outsiders a mechanism to coordinate their harvests (e.g., communication) so we do not anticipate that they will be able to develop cooperative strategies. We provide a cooperative benchmark for the outsiders in Table 1 for the Baseline Treatment to show how the subjects' choices in this treatment compare to pure Nash strategies and group-optimal strategies, which are standard comparisons in social dilemma games.
} 
the outsiders would earn about $64.4 \%$ more with a coordinated harvest strategy than behaving non-cooperatively.

The primary purpose of the Baseline treatment was to serve as a reference point when testing for the effects of the other treatments. Communication is widely known to improve outcomes in CPR settings (Ostrom and Walker 1991, Ostrom 2006), and we therefore expect the insiders to sustain the resource longer and earn a greater share of the cooperative earnings than the non-cooperative benchmark.

T2. Poaching: The Poaching treatment gave outsiders the ability to harvest from both zones, subject to the individual harvest limit of 5 locos in total. There was no monitoring or sanctioning of poaching from the blue zone by the outsiders. Insiders could only harvest blue locos and could not poach from the outsiders.

The outsiders, behaving non-cooperatively, would use their harvest capacity to first harvest from the inside (blue) zone. After the inside zone was depleted, the outsiders would move to the outside (yellow) zone and harvest at capacity there until the zone was depleted. Recognizing that it is impossible to deter poaching, there is no incentive for the insiders to cooperate by limiting their harvests to conserve their resource. Therefore, the insiders would harvest at capacity until their blue zone was depleted, and as a result, there is no cooperative equilibrium. Table 1 reveals that harvesting at capacity by both insiders and outsiders in the blue zone would deplete it in just two periods. Since the outsiders would not harvest in their zone while they were poaching in the blue zone, the yellow zone would last for five periods until it was depleted. Note the dramatic effect that unrestricted poaching has on the welfare of the insiders. Specifically, they would earn $50 \%$ less than in the non-cooperative outcome in the Baseline treatment and $70 \%$ less than in the cooperative outcome.

In this treatment, we expect that unrestricted poaching in the blue zone would undermine cooperation by the insiders. As a result, relative to the Baseline treatment, insiders' earnings in the Poaching treatment will be lower and the blue resource will not last as long.

T3. External Enforcement: This treatment was the same as the Poaching treatment except that outsiders were monitored with an exogenous probability of $11.1 \%$. (We will be specific about 
how monitoring was implemented in subsection 3.2). If an outsider was caught harvesting locos from the blue zone, a fine was imposed of 2,000 Chilean pesos per blue loco harvested. Note that the expected per unit sanction in this treatment was well below the value of a harvested loco of 500 pesos, and therefore in theory, external enforcement should have no impact on poaching behavior. Therefore, the equilibrium harvest paths in this case are the same as in the Poaching treatment in which there was no sanction for poaching. Likewise, payoffs for the insiders are the same in the Poaching and External Enforcement treatments. However, expected payoffs for the outsiders would be reduced by the amount of the expected sanctions.

While our benchmarks suggest that we should observe no difference in behavior between the External Enforcement treatment and the Poaching treatment, it is possible that the outsiders would respond to the low expected sanction in the External Enforcement treatment by reducing their poaching. This kind of behavior has been observed in other framed field experiments like ours (e.g., Vélez et al. 2010, Lopez et al. 2012) and in laboratory experiments involving compliance and enforcement (e.g., Alm and McKee 1998, Torgler 2002, Murphy and Stranlund 2007). If we do observe less poaching in the External Enforcement treatment relative to the Poaching treatment, we might also observe more sustained harvests from the blue zone and higher payoffs for the insiders.

T4-Local Enforcement: This treatment was the same as the Poaching treatment except that the insiders could invest in monitoring the outsiders to detect poaching. In every period, each insider privately made both a harvest decision and a decision to contribute to a collective investment in monitoring. The marginal cost of increasing the monitoring probability by an additional 5.56 percentage points was 250 pesos, and each of the three insiders could contribute 0,250 or 500 pesos. The cumulative investment by the insiders determined the monitoring probability according to the schedule $(0 \%, 5.6 \%, 11.1 \%, 16.7 \%, 22.2 \%, 27.8 \%, 33.3 \%)$. In a real-world TURF, if members monitor the resource and catch a poacher, the outsider is handed over (or reported) to the authorities for prosecution. Therefore, to reflect our motivating context, the insiders could invest in monitoring the resource, but they could not keep any of the fines collected. Given the 2,000 pesos per unit poaching sanction and the 500 pesos unit value of a loco, the minimum monitoring to deter risk-neutral outsiders in a period was $27.8 \%$, which would collectively cost the inside group 1,250 pesos. If the insiders failed to reach this level of 
monitoring, then the resulting expected sanction would be insufficient to deter the outsiders at all. Moreover, if the outsiders were not deterred, then they would poach to capacity in the blue zone until it was depleted. Thus, the collective value of deterrence for the group of insiders in a period was the value of the 15 blue locos that would be poached in the absence of deterrence, that is, 7,500 pesos. Since the insiders could fully deter the outsiders in a period if they spent 1,250 pesos, it was always worthwhile for the insiders as a group to invest in complete deterrence. Whether the insiders were able to coordinate their monitoring investments well enough to deter poaching is one of central questions of this study.

The benchmark outcomes for the Local Enforcement treatment listed in Table 1 assume that the insiders fully deter the outsiders (at least until the end period) at minimum monitoring cost. If the insiders also coordinate their harvest choices, then they would pursue the strategy of maintaining maximum sustained yield until the last several periods in which they would harvest at capacity so that the stock was below its critical level at the end of period 10. In the final period there would be sufficient stock remaining so that both insiders and outsiders could harvest at capacity. Thus, there would be no reason for the insiders to try to deter the outsiders in the last period. The insiders' total cost of deterrence over nine periods is 11,250 pesos. Note that no sanctions would be levied on the outsiders because poaching would be successfully deterred.

In Table 1, we also present the outcome in which the insiders are not able to coordinate their harvests, but they are able to deter the outsiders. In this case the blue zone would be depleted in four periods. In that fourth period, there would be sufficient stock of the blue resource so that both insiders and outsiders could harvest at capacity. Thus, the insiders could maintain their deterrence of the outsiders for only three periods, at a total cost of 3,750 pesos. Again, outsiders would never be sanctioned.

Of course, deterring the outsiders required a significant amount of coordination. If the insiders were unable to coordinate their monitoring investments well enough, then they would not deter the outsiders and it would be wasteful to invest in any monitoring. In this case, the equilibrium outcomes in this treatment are the same as in the Poaching treatment. Note that the value of cooperating on harvests is zero if the insiders do not simultaneously coordinate their monitoring investments. Table 1 also reveals that the insiders would always be better off if they could deter the outsiders, regardless of whether they could coordinate their harvest strategies. To 
see this, note that the insider payoffs for the Local Enforcement benchmarks are higher than their payoffs under undeterred poaching in the Poaching treatment.

Since it would be worthwhile for the insiders to deter the outsiders in the Local Enforcement treatment, we expect them to try to do so (i.e., insider investments in monitoring will not be zero). The success of these monitoring investments will depend on how large they were and how the outsiders responded. Since coordinating their harvest choices is worthwhile when the insiders can deter the outsiders, investments in monitoring may be associated with greater sustained harvests in blue zone. We therefore expect that the insiders will invest in monitoring in the Local Enforcement treatment. As a result, relative to the Poaching treatment, there will be lower poaching, higher insider harvests, and higher insider earnings.

T5-External + Local Enforcement: This treatment combined the enforcement strategies of the External and the Local enforcement treatments. The government contributed $11.1 \%$ monitoring at no cost to the insiders. The insiders' contribution to monitoring produced a multinomial distribution with probabilities $(11.1 \%, 16 \%, 21 \%, 25.9 \%, 30.8 \%, 35.8 \%$, and $40.7 \%)$. As in the Local Enforcement treatment, each step beyond the first could be purchased for 250 pesos and individual insiders could contribute 0,250 or 500 pesos. The cumulative investment by all three insiders determined the level of monitoring. To deter the outsiders in a period, the insiders only needed to invest enough to get the monitoring probability to $25.9 \%$, which collectively cost 750 pesos. It was always worthwhile for the insiders to make this investment, so the full-deterrence outcomes in this treatment are the same as for the Local Enforcement treatment, except that deterrence is cheaper for the insiders. If the insiders were not able to coordinate their investments in monitoring well enough to deter the outsiders, the benchmark outcome in this treatment would be the same as for the External Enforcement treatment.

Observed differences between the External + Local Enforcement treatment and the Local Enforcement treatment would likely depend on how the insiders' investments in monitoring differed between the two treatments. It is possible that they are able to better deter the outsiders since deterrence is cheaper, in which case we would observe less poaching and higher insider harvests and payoffs relative to the Local Enforcement treatment. On the other hand, it is possible that the insiders would use government monitoring to reduce their own monitoring investments so that deterrence of the outsiders would be unchanged. Therefore, it is 
unclear how insider investments in monitoring will differ between the Local Enforcement and External + Local Enforcement. However, it is unlikely that poaching would increase in this treatment relative to the Local Enforcement treatment.

\subsection{Procedures}

The experiments were conducted with members of fishing organizations operating under the Management and Exploitation Areas of Benthic Resources (MEABR) system in the Biobío region in central-southern Chile, about 300 miles south of Santiago. Invitations to participate in the experiments were extended through the leader of each TURF. Efforts were made to recruit participants from all the TURFs operating in the sample area. A total of 210 TURF members were recruited from the following communities: Coliumo, Cerro Verde Bajo, Lirquén, Chome, Maule, Lota, Llico, Arauco, Los Piures, Rumena, Punta Lavapie, and Perone. ${ }^{12}$ Treatments were distributed across the communities in randomized blocks to avoid concentrating particular treatments in particular communities. In addition, we conducted the same experiments with 204 students recruited from the Universidad de Concepción, located in the same region. A summary of the number of subjects and groups by treatment is contained in Table 2 .

\section{<INSERT TABLE 2>}

Upon arrival, participants signed consent forms and were then randomly assigned to groups of six, with three in the blue group (the insiders) and three in the yellow group (the outsiders). A maximum of two groups of six participated in a particular session. At the beginning of each session, the experimenter read the instructions aloud with PowerPoint slides highlighting the key points. ${ }^{13}$ Practice rounds were conducted to familiarize the participants with the procedures. Control questions were asked about the procedures to determine whether the subjects were ready to participate in the experiments. The experiments were conducted with pen and paper. Insiders and outsiders were separated so that there was enough space for each subject to work in private.

\footnotetext{
${ }^{12}$ See section 2 of the online Appendix for details about each TURF and its location.

${ }^{13}$ Both English and Spanish versions of the instructions are available in section 3 of the online Appendix <We will insert URL for journal's supplemental content.>
} 
In each round of the experiments, the insiders were first asked to leave the room to communicate with each other about any aspect of the activity for a maximum of three minutes. An experimenter accompanied the group to monitor communication and ensure no inappropriate language was used. Outsiders remained seated in silence. When the insiders finished the communication stage, all subjects wrote down their decisions in private. In every round of each treatment, both insiders and outsiders decided how many locos to harvest. In treatments T2 through T5, the outsiders chose how much they would harvest in their yellow zone and how much to poach from the blue zone. In addition, in the Local Enforcement and External + Local Enforcement treatments, the insiders chose their investments in monitoring.

Following Cárdenas et al. (2013), to help participants visualize the state of the resource, the two zones were represented as blue and yellow tokens on a board in the front of the room. At the end of each round, we announced the total harvest in each zone and removed the appropriate number of tokens, or locos, from the board. Individual choices were not publicly revealed, and in treatments with poaching, only the total harvest from the blue zone was announced; participants did not know how much of the blue harvest was from poaching. We then announced the regrowth in each zone, placed those tokens on the board, and announced the new initial biomass for the next round.

In the three enforcement treatments, after the aggregate harvest was announced and removed from the board, the experiment proceeded to a monitoring stage. In the External Enforcement treatment, we used a custom 6-sided die to determine whether an outsider was inspected. Two sides of the die had the word "yes" printed on it while the other four sides had the word "no." One outsider would be inspected if a "yes" was rolled. To determine which outsider would be inspected, another custom six-side die was rolled. This die had the outsider participant numbers 4,5 , or 6 on two sides of the die. This process produced a probability of $11.1 \%$ that one outsider would be inspected.

To determine monitoring in the Local Enforcement treatment, a standard six-sided die was used. Each insider was allowed to purchase up to two sides of the die to determine whether one outsider participant was inspected. Each side cost 250 pesos. The more sides the insiders collectively purchased, the more likely an outsider participant would be inspected. For example, if the insiders purchased three sides (at a total cost of 750 pesos), then one outsider would be inspected if the numbers 1, 2, or 3 were rolled. If the insiders purchased five sides (at a total cost 
of 1,250 pesos), then one outsider would be inspected if any of the numbers 1 through 5 were rolled. To determine which outsider would be inspected, we again used our die with the outsider participant numbers 4,5 , or 6 on two sides of the die. This process produces alternative levels of monitoring $(0 \%, 5.6 \%, 11.1 \%, 16.7 \%, 22.2 \%, 27.8 \%, 33.3 \%)$, with each increment costing an additional 250 pesos.

To determine monitoring in the combined External + Local Enforcement treatment, we simply combined the procedures in the External Enforcement and Local Enforcement treatments. We first implemented the External Enforcement monitoring process all the way through to sanctioning poaching if discovered. We then implemented the Local Enforcement process all the way to sanctioning. In contrast to the External Enforcement and Local Enforcement treatments, in the External + Local Enforcement treatment up to two outsiders could be sanctioned, but a single outsider could not be sanctioned twice. The process of determining monitoring in the External + Local Enforcement treatment produced alternative monitoring probabilities (11.1\%, $16 \%, 21 \%, 25.9 \%, 30.8 \%, 35.8 \%$, and $40.7 \%$ ), with each increment costing 250 pesos.

Each session lasted about two hours and thirty minutes. At the end of the experiment, participants were paid their accumulated earnings in cash. Earnings for TURF members averaged 13,874 Chilean pesos $(\sigma=5,557)$, with a range of 5,000 to 29,500. Earnings for the student participants averaged 14,240 Chilean pesos $(\sigma=4,668)$, with a range of 5,500 to 27,500. These figures include fixed initial payments of 2,500 pesos for insiders and 7,500 pesos for outsiders. The outsiders received more because of the lower initial stock of their resource. At the time the experiments were conducted, the exchange rate was 625 Chilean pesos to one US dollar.

Participants were given a survey to complete at the end of each session to gather socio-economic information as well as the TURF members' perceptions of poaching activity and enforcement actions in their TURF.

\section{Results}

\subsection{Participant characteristics}

Most of the TURF participants were male (76\%). Their mean age was about 49 years old $(\sigma=$ 12.3) with about 7.8 years of formal schooling $(\sigma=3.1)$. The mean number of years living in the same fishing village was $43(\sigma=14.5)$. The majority of the TURF participants were the main 
contributors to their family incomes (83\%). Mean monthly family income was about 230,000 Chilean pesos (about US\$ 368 given the exchange rate at the time); only 6\% had monthly incomes above 450,000 Chilean pesos (about US\$ 720). We also asked the participants about their main activity in their TURF: $20 \%$ were boat owners, $21 \%$ were divers, $21 \%$ were fishermen/crew members, and 19\% were seaweed collectors. The remaining $19 \%$ reported that they were boat operators, assistants to divers, seafood collectors, administrators, and other. The majority of student participants were male $(55 \%)$. The mean age was 22 years old $(\sigma=2.0)$ with about 15 years of formal schooling $(\sigma=1.7)$. Participants were completing a wide variety majors at Universidad de Concepción, and about $36 \%$ were majoring in Commercial Engineering (i.e., economics and business administration).

Participants in the field experiments reported that poaching in their TURF was an important problem. The mean response on a scale from 1 to 10 from "poaching is an irrelevant problem" to "poaching is a very relevant problem" was 7.8. Approximately $70 \%$ of participants believed that both the fishers' organization and the government are jointly responsible for monitoring and enforcement to prevent poaching in the TURFs. $80 \%$ of the participants reported that their organizations actively monitor their TURF and the majority reported that members of the TURF patrol their fishing area. Participants perceived that the monitoring efforts of the National Fisheries Service or the Navy are not very effective. The mean response on a scale from 1 to 10 that patrolling by the government is "ineffective" to "very effective" was 3.2. Finally, we asked the participants what happens when someone was caught poaching: $50 \%$ of the participants responded that the poachers would be reported to the authorities, but would not be sanctioned; $35.2 \%$ reported that the poacher would be reported to the authorities and sanctioned; $7.4 \%$ responded that nothing would happen; and $7.4 \%$ mentioned that there might be other minor consequences. These results suggest that the TURF members in our study region were not confident of the ability of the federal government to protect their use rights. This is consistent with results by Davis et al. (2017) who surveyed TURF members closer to Valparaiso, Chile (significantly north of our study region) and found similar concerns about the ineffectiveness of government monitoring and sanctioning efforts to deter poaching. 


\subsection{Experiment results}

Figures 1-6 summarize the key outcome variables for both the TURF members and students. We focus the discussion of results on testing for treatment effects for the insiders as well as poaching levels in the blue zone. In Figures 1-5 we have indicated cooperative and non-cooperative outcomes. The non-cooperative outcomes are those for which the insiders do not coordinate their harvests and they do not deter the outsiders at all. This outcome is the same for all but the Baseline treatment, which has no poaching by design. We do not include cooperative outcomes for the Poaching and External Enforcement treatments, because no cooperative equilibrium exists in these treatments. Figure 1 presents the evolution of the mean ending biomass over time in the blue zone for TURF members and students in each treatment. Ending biomass refers to the stock level after harvests in a period, but before the new growth occurs to start the next period. Figure 2 presents mean terminal periods for the blue zone, while Figure 3 presents mean individual cumulative harvests in the blue zone. Figure 4 presents mean individual cumulative earnings by the insiders. Figure 5 presents mean individual cumulative poaching by the outsiders in the blue zone. Figure 6 is somewhat different in that it presents the data on monitoring probabilities achieved by the insiders in the Local and External + Local Enforcement treatments.

Statistical tests are conducted using the random effects models presented in Tables 3-6. Each of these tables presents five models. Models 1-4 use the field experiment data with TURF members. Model 1 includes dummy variables for treatment effects and survey responses about subject characteristics (age, gender and education). Model 2 adds fixed effects for each community. Model 3 adds responses to survey questions regarding individual perceptions of the problem of poaching in the community, whether TURF members monitor the resource, the effectiveness of monitoring by the external authorities, and the effectiveness of local monitoring by the TURF. Model 4 includes both community fixed effects and individual perceptions about monitoring and poaching. Finally, Model 5 is identical to Model 1 but uses the lab experiment data with student subjects.

For the most part, the treatment effects for TURF members and students were qualitatively similar even if the magnitudes differ. Relative to the Baseline, poaching without monitoring depleted the blue resource sooner and reduced insider earnings. In theory, weak external monitoring should have no impact on poaching behavior, but it did have a modest effect in the field. When the insiders were given the opportunity for local monitoring, they failed to 
coordinate their contributions to collective monitoring sufficiently to fully deter poaching, but they did make positive investments in monitoring which resulted in partial deterrence. Finally, local monitoring combined with external monitoring was still insufficient to deter poaching completely. Nevertheless, mean poaching gains for outsiders were negative when local monitoring was combined with external monitoring.

\subsubsection{Baseline Treatment}

Recall that outsiders had no opportunity to poach in the insiders' zone in the Baseline treatment. Figure 1 shows that average stocks of the blue resource over time were slightly below the cooperative outcome, and significantly better than the non-cooperative prediction. Moreover, Figure 2 shows that all groups (both TURF members and students) successfully sustained their blue resource for all ten periods. In fact, five of the seven TURF insider groups had sufficient stock remaining to continue harvesting in an $11^{\text {th }}$ period if this had been allowed. Consistent with the stock paths in Figure 1, Figure 3 shows that mean individual cumulative harvests in the blue zone were higher than the non-cooperative outcome. Consequently, the insiders earned significantly more than the non-cooperative level of earnings (Figure 4), which is consistent with the literature that shows that the ability to communicate improves cooperation in social dilemmas (Ostrom 2006). Insider TURF members in the Baseline treatment earned about 13,095 pesos on average, which is about mid-way between the non-cooperative $(10,000)$ and the cooperative equilibrium earnings $(16,655)$. The student insiders were more successful in coordinating their harvests than the TURF members; as a result, their earnings were higher $(15,139)$ and were $90 \%$ of the earnings in the cooperative equilibrium.

\section{$<$ INSERT FIGURES 1,2,3,4>}

In contrast, earnings of the student and TURF member outsiders were much closer to the non-cooperative outcome. Outsider TURF members earned 8,000, which is only $6.7 \%$ higher than the non-cooperative prediction $(7,500)$. Similarly, student outsiders averaged 8,333 in earnings in the Baseline.

Interestingly, six of the seven outsider groups in the field experiments also sustained the yellow resource for all ten periods. The student outsider groups depleted the yellow zone more 
quickly, in about 7.7 periods on average, but this is still much longer than the non-cooperative benchmark of three periods. These findings are interesting considering that the outsiders could not communicate with each other, and hence, had no direct way to coordinate their harvests. In a series of dynamic framed field experiments, Janssen et al. (2013) also found a tendency for subjects to sustain resources for much longer than non-cooperative predictions when they could not communicate with each other. Cárdenas et al. (2013) report similar outcomes in both forestry and irrigation field experiments. Cárdenas (2009) discusses post-experiment interviews and suggests that this pattern of conserving the resource is not due to error, but rather that the field participants link conserving the resource in the experiment to conservation of the resource they use in their real lives.

\subsubsection{Poaching Treatment}

Results from the Poaching treatment are consistent with our expectation that, relative to the Baseline treatment, insiders' earnings would be lower and the blue resource would not last as long. Figures 1 and 2 show the blue resource was depleted more quickly in the Poaching treatment than in the Baseline. Figure 2 shows that mean terminal dates for the blue zone fell with undeterred poaching (6.7 periods for the TURF groups and 4.6 periods for the student groups, as compared to 10 periods in the Baseline), but do not approach the non-cooperative level ( 2 periods). The regression coefficients on the Poaching dummy variable in Tables 3 and 4 show that cumulative harvests and earnings by both TURF and student insiders in this treatment were dramatically lower than in the Baseline treatment. In fact, Figures 3 and 4 show that mean cumulative harvests and earnings for both TURF and student insiders were quite close to the non-cooperative equilibrium. It is clear that undeterred poaching largely eliminated the insiders' ability to coordinate their harvests and sustain the resource to improve on the non-cooperative outcome. This is similar to what Schmitt et al. (2000) found in their laboratory experiments.

\section{$<$ INSERT TABLES 3-4>}

Not surprisingly, the earnings for the outsiders were significantly higher in the Poaching treatment than in the Baseline. Mean earnings were 79\% higher for the TURF outsiders and 57\% higher for the student outsiders. Mean poaching levels by outsiders in the blue zone (Figure 5) 
for both TURF members (12.57 locos) and students (8.95 locos) were close to the noncooperative equilibrium (10 locos). Recall that mean harvests and earnings for student and TURF outsiders in the yellow zone were also close to the non-cooperative prediction in the Baseline treatment. These values remain close to the non-cooperative outcome in the Poaching treatment. In addition, mean terminal periods in the yellow zone were comparable to the mean terminal periods in the Baseline treatment.

\section{$<$ INSERT FIGURE 5>}

\subsubsection{External Enforcement}

Recall that in this treatment, the outsiders were monitored with an exogenous probability of $11.1 \%$ and were sanctioned with a 2,000 pesos fine per unit poached from the blue zone. Given that the value of a loco is 500 pesos, the expected marginal fine (222 pesos) was not sufficient to deter poaching. Therefore, outcomes should be identical to the Poaching treatment. However, Figure 5 shows that mean poaching by outsider TURF members in the blue zone fell from 12.57 locos in the Poaching treatment to 9.54 locos with external enforcement. The models in Table 5 reveal that this decrease is statistically significant. As noted earlier, this is consistent with results observed in both framed field and laboratory experiments. The effect of weak external enforcement on poaching by student outsiders was smaller (from 8.95 to 7.76 locos) and not statistically significant (Table 5).

\section{<INSERT TABLE 5>}

In response to the reduced poaching, mean harvests by insiders in the blue zone for both TURF members and students increased about $40 \%$ over the Poaching treatment (Figure 3 ). The increased harvests by the insiders over the Poaching treatment yielded higher earnings for both the insider TURF members and the insider students (Figure 4). This increase in insider harvests was statistically significant in three of the four models for the TURF members, and was also statistically significant for the students (Table 3). ${ }^{14}$ Because of the reduced poaching, Figures 1

\footnotetext{
${ }^{14}$ In this treatment, insider earnings are a constant multiple of harvest and therefore the patterns discussed pertaining to insider harvests are identical to those for insider earnings.
} 
and 2 show that TURF members and student groups were able to sustain the resource longer than in the Poaching treatment. These results suggest that weak external enforcement can provide a modest deterrent to poaching despite incentives to the contrary.

\subsubsection{Local Enforcement}

Recall in the Local Enforcement treatment that insider groups were incentivized to invest enough in monitoring to completely deter the outsiders from poaching in the blue zone, but that doing so would have required that they coordinate their investment choices. However, Figure 5 shows that neither the insider TURF members nor students were able to fully deter poaching. Figure 6 presents the data on monitoring levels along with the time series of average probabilities across groups for the Local Enforcement (left panels) and External + Local Enforcement treatments (right panels). Note that most groups in the Local Enforcement treatment did not reach the 25\% monitoring probability needed for full deterrence (i.e., the level of monitoring such that the expected sanction exactly equals the loco price). In fact, some groups did not invest in monitoring at all. Thus, insiders were not able to deter the outsiders in the Local Enforcement treatment simply because they did not invest enough in monitoring.

\section{$<$ INSERT FIGURE 6>}

While it is clear that the insiders were not able to coordinate their monitoring investments well enough to deter the outsiders fully, on average the insiders made positive investments in monitoring. Consequently, relative to the Poaching treatment, outsiders poached less (Figure 5 and Table 5), although there is some variation in levels of statistical significance among the regression models for the TURF outsiders. Both TURF and student insiders harvested more in the blue zone under the Local Enforcement treatment than in the Poaching treatment (Figure 3 and Table 3), and the combination of lower poaching and higher harvests led to higher earnings for insiders than in the Poaching treatment (Figure 4). From Table 4, this increase in earnings is statistically significant for the student insiders and in three out of four models for the TURF insiders.

It is interesting that the poaching behaviour of the outsiders was about the same in the External Enforcement and Local Enforcement treatments (Figure 5 and Table 5). These results 
suggest that limited monitoring, whether provided by an external authority or the common pool resource users themselves, can partially deter poaching.

As poaching was about the same under the External Enforcement and Local Enforcement treatments, so too were insider harvests in the blue zone (Figure 3 and Table 3). Earnings were somewhat lower for insiders (Figure 4), but this was mainly due to their investments in monitoring and the differences were not statistically significant (Table 4).

\subsubsection{External + Local Enforcement}

In this treatment, the external authority contributed $11.1 \%$ monitoring, so achieving a level of monitoring sufficient to deter poaching (i.e., at least 25\%) was cheaper for insiders than in the Local Enforcement treatment. Thus, poaching should not be greater in the External + Local Enforcement treatment than in the Local Enforcement treatment. Interestingly, Figure 5 suggests that mean levels of poaching were about the same in the External + Local Enforcement treatment as in the Local and External Enforcement treatments. In fact, a joint test fails to reject the hypothesis that poaching levels in the External, Local, and External + Local Enforcement treatments were the same (Table 5). It is clear that combining exogenous external monitoring with endogenous local monitoring did not allow the insiders to deter the outsiders more effectively.

However, monitoring was somewhat higher under the External + Local Enforcement treatment for both students and TURF members (Figure 6). With Local enforcement only, the mean monitoring probability was $14 \%$ for TURF members and $18 \%$ for students, whereas when Local and External enforcement was combined, the mean was 20\% (TURF) and 23\% (students), including the $11 \%$ that was provided by the external authority. To test whether individual investments in monitoring differed between the two treatments, we estimated the random effects tobit model in Table 6. Results indicate that there is not a statistically significant treatment effect, which suggests that on average individual contributions to monitoring are not affected when local enforcement is supplemented by an external authority. This result holds for both TURF members and students. ${ }^{15}$

\footnotetext{
${ }^{15}$ We also estimated a random effects probit model which tested whether the binary decision about whether to invest in monitoring varied by treatment. Consistent with the results in Table 6 , there are no statistically significant differences in the two treatments. A reviewer suggested that external monitoring might improve coordination among insiders by reducing the variance of individual contributions to monitoring without changing the group mean. To
} 


\section{$<$ INSERT TABLE 6>}

Because of higher monitoring but little change in poaching, the outsiders bore higher sanctions in the External + Local Enforcement treatment than under the Local Enforcement treatment. This was true in particular for the TURF members. In fact, the mean net revenue from poaching by outsiders was negative for both TURF members (-1748) and students (-24), suggesting that poaching was not worthwhile, on average.

Harvests of both insider TURF members and students were not significantly different between the External + Local Enforcement and the Local Enforcement treatments (Table 3). A joint test failed to reject the hypothesis that insider harvests in the External, Local, and External + Local Enforcement treatments were the same (Table 3). We also note little difference in the paths of mean biomass stocks in Figure 1 for the External, Local, and External + Local Enforcement treatments. Because insider harvests were similar in the External and the External + Local Enforcement treatments and because the insiders invested about the same amount in monitoring in the two treatments, insider earnings in the two treatments were not statistically different from one another (Table 4). A joint test fails to reject the hypothesis that insider earnings were equal in the External, Local, and External + Local Enforcement treatments (Table 4).

\section{Conclusions}

We have presented the results of framed, dynamic common pool resource experiments that were designed to investigate the effects and deterrence of poaching. We found that resource users could sustain their resource for the length of the experiment and extract a significant portion of the available harvesting surplus in the absence of a poaching threat. However, they were unable to do so in the presence of unmonitored and unsanctioned poaching. Weak external monitoring for poaching that was not sufficient to lift the expected marginal sanction above the unit value of poaching actually led to significantly lower poaching in the field. Similar findings have been 
found in other laboratory and field experiments that feature low expected sanctions for undesirable behaviour.

Giving the resource users the opportunity to invest in their own monitoring did not change the results much relative to weak external monitoring. They could not coordinate their investments in monitoring well enough to fully deter poaching, even though they would have been significantly better off if they had been able to do so. Despite not being able to deter encroachment completely, the insiders made positive investments in monitoring which resulted in partial deterrence of poaching.

While we expected that combining weak external monitoring with local investments in monitoring would have produced more effective deterrence, poaching was not significantly different under this condition than under weak external monitoring alone and under insider monitoring alone. However, we have reason to doubt that this result would persist in natural settings. Monitoring was somewhat higher with external and local monitoring combined and mean poaching earnings were negative. It is unlikely that negative poaching gains would persist in actual settings.

A unique feature of our study is that we conducted the same framed experiments with members of local TURFS on the south-central coast of Chile and with students from a local university. We did so to determine whether there would be significant differences in behaviour under the same experimental conditions. While we found some differences, the behaviour of the TURF members and the university students were quite similar so that our main results are robust to differences in the subject populations.

Of course, there are several ways to extend our work. Perhaps specific coordination devices like voting on group monitoring investments would allow local resource users to better deter poaching. Voting on group decisions is common among Chilean TURFS.

Additional experiments that vary key parameters of the problem may shed additional light on individual and group incentives to conserve and defend territorial use rights and resources. For example, we might suspect that higher sanctions or lower marginal monitoring costs would allow resource users to defend against encroachment more easily. On the other hand, a more abundant or more productive resource might simultaneously increase the incentive to protect the resource and to poach from it. Environmental and climatic variability and others sources of uncertainty 
may also affect resource users' ability to coordinate their harvests and defend their resource, as well as the incentives for outsiders to poach.

Other potentially informative extensions might make membership in insider and outsider groups endogenous. Membership in TURFS along the coast of Chile was not determined exogenously, but assignment to groups in our experiments was determined randomly. Key parameters like resource abundance, sanctions, and marginal monitoring costs can affect the willingness of harvesters to participate in a TURF. For example, harvesters may not be willing to bind themselves to the rules of a TURF if the consequences of poaching are low. Conversely, severe consequences for poaching may make joining a TURF more attractive.

Finally, while this paper has focused on aggregate outcomes, a better understanding of individual behavior would also be useful. This could include both the design of mechanisms to encourage insiders to make sufficient investments to deter poaching, and an exploration of the factors that motivate individuals to poach. In general, gaining a greater understanding of poaching and its deterrence will likely have important consequences for the formation and management of common pool resource cooperatives. 


\section{References}

Abatayo, A.L. and Lynham, J., 2016. Endogenous vs. exogenous regulations in the commons. Journal of Environmental Economics and Management 76, 51-66.

Aburto, J., G. Gallardo, W. Stotz, C. Cerda, C. Mondaca-Schachermayer, and K. Vera. 2013. Territorial user rights for artisanal fisheries in Chile - intended and unintended outcomes. Ocean \& Coastal Management 71, 284-295.

Alm, J. and McKee, M., 1998. Extending the lessons of laboratory experiments on tax compliance to managerial and decision economics. Managerial and Decision Economics, 259-275.

Bell, P., Peterson, T. and Hauktaluoma, J. (1989). The effect of punishment probability on overconsumption and stealing in a simulated commons. Journal of Applied Social Psychology $19,1483-1495$.

Bustamante, R and Castilla, J., 1987. The shellfishery in Chile: An analysis of 26 years of landings (1960-1985). Revista Biología Pesquera.16, 79-97.

Bustos, E., A. González and F. Ponce. 1991. 'Repoblación de recursos bentónicos: mecanismos de recuperación de poblaciones sobreexplotadas. Rev. Pacífico Sur. 19:35

Camerer, C. F., Dreber, A., Forsell, E., Ho, T. H., Huber, J., Johannesson, M., and Heikensten, E., 2016. Evaluating replicability of laboratory experiments in economics. Science 351(6280), 1433-1436.

Cancino, J., Uchida, H., and Wilen. J.E., 2007. TURFs and ITQs: coordinated vs. decentralized decision making. Marine Resource Economics 22(4), 391-406.

Cárdenas, J-C., Stranlund, J. and Willis, C., 2000. Local environmental control and institutional crowding-out. World Development 28(10), 1719-1733.

Cárdenas, J-C., 2009. Experiments in environment and development. Annual Review of Resource Economics 1, 157-162.

Cárdenas, J-C., Janssen, M. and Bousquet, F., 2013. Dynamic rules and resources: three new field experiments on water, forests and fisheries. In Handbook on Experimental Economics and the Environment. Edited by John A. List and Michael K. Price. Northampton, MA: Edward Elgar.

Cárdenas, J-C. and Ostrom, E. 2004. What do people bring into the game? Experiments in the field about cooperation in the commons. Agricultural Systems 82, 307-326

Carlsson, L. and Berkes, F., 2005. Co-management: concepts and methodological implications. Journal of Environmental Management 75(1), 65-76.

Charles, A.T., 2002. Use rights and responsible fisheries: Limiting access and harvesting through rights-based management. In K. Cochrane, editor, A Fishery Manager's Guide-book.

Management measures and their applications. FAO Fisheries Technical Paper, No 424, 231 p.

Chávez, C., J. Dresdner, M. Quiroga, M. Baquedano, N. González, and R. Castro. 2010. Evaluación socio-económica de la pesquería del recurso loco asociada al régimen de areas de manejo, como elemento de decisión para la administración pesquera. Informe Final. Proyecto FIP 2008-31. 
Christy, F.T., 1982. Territorial use rights in marine fisheries: definitions and conditions. FAO Fisheries Technical Paper 227, 10 p.

Davis, K.J., Kragt, M.E., Gelcich, S., Burton, M., Schilizzi, S. and Pannell, D.J., 2017. Why are fishers not enforcing their marine user rights? Environmental and Resource Economics 67(4), 661-681.

De Geest, L.R., Stranlund, J.K. and Spraggon, J.M., 2017. "Deterring poaching of a common pool resource: an experimental evaluation.” Journal of Economic Behavior and Organization $141,254-276$.

DeAngelo, G., Humphreys, B., Reimers, I., 2017. Are public and private enforcement complements or substitutes? Evidence from high frequency data. Journal of Economic Behavior and Organization 141,151 - 163.

Dreber, A., Pfeiffer, T., Almenberg, J., Isaksson, S., Wilson, B., Chen, Y., and Johannesson, M., 2015. Using prediction markets to estimate the reproducibility of scientific research. Proceedings of the National Academy of Sciences 112(50), 15343-15347.

Fehr, E. and Gächter, S., 2000. Cooperation and punishment in public goods experiments. American Economic Review 90(4), 980-994.

Gelcich, S. N. Godoy, and J.C. Castilla. 2009. “Artisanal fishers' perceptions regarding coastal co-managements policies in Chile and their potentials to scale-up marine biodiversity conservation." Ocean \& Coastal Management 52, 424-432.

Gelcich, S., Cinner, J., Donlan, C.J., Tapia-Lewin, S., Godoy, N. and Castilla, J.C., 2017. Fishers' perceptions on the Chilean coastal TURF system after two decades: problems, benefits, and emerging needs. Bulletin of Marine Science 93(1), 53-67.

Gelcich, S., Guzman, R., Rodríguez-Sickert, C., Castilla, J.C. and Cárdenas, J-C., 2013. Exploring external validity of common pool resource experiments: insights from artisanal benthic fisheries in Chile. Ecology and Society 18(3).

Gonzalez, J., Stotz, W., Garrido, J., Orensanz, J. M., Parma, A. M., Tapia, C., and Zuleta, A., 2006. The Chilean TURF system: how is it performing in the case of the loco fishery? Bulletin of Marine Science 78(3), 499-527.

Harrison, G.W. and List, J.A., 2004. Field experiments. Journal of Economic Literature 42(4), 1009-1055.

Janssen, M. A., Bousquet, F., Cárdenas, J-C., Castillo, D., and Worrapimphong, K., 2013. Breaking the elected rules in a field experiment on forestry resources. Ecological Economics 90, 132-139.

Leiva, G.E. and Castilla, J.C., 2002. A review of the world marine gastropod fishery: evolution of catches, management and the Chilean experience. Reviews in Fish Biology and Fisheries 11, 283-300.

Lopez, M.C., Murphy, J.J., Spraggon, J.M. and Stranlund, J.K., 2012. Comparing the effectiveness of regulation and pro-social emotions to enhance cooperation: experimental evidence from fishing communities in Colombia. Economic Inquiry 50(1), 131-142. 
Moreno, A. and Revenga, C., 2014. The System of territorial use rights in fisheries in Chile. The Nature Conservancy, Arlington, VA, USA.

Murphy, J.J. and Stranlund, J.K., 2007. A laboratory investigation of compliance behavior under tradable emissions rights: Implications for targeted enforcement. Journal of Environmental Economics and Management 53(2), 196-212.

Ostrom, E., 1990. Governing the commons: the evolution of institutions for collective action. Cambridge University Press.

Ostrom, E., 2006. The value-added of laboratory experiments for the study of institutions and common-pool resources. Journal of Economic Behavior \& Organization 61(2), pp.149-163.

Ostrom, E., Walker, J., 1991. Communication in a commons: cooperation without external enforcement. In: Palfrey, T.R. (Ed.), Laboratory Research in Political Economy. University of Michigan Press, Ann Arbor, pp. 287-322.

Ostrom, E., Walker, J., and Gardner, R. 1992. Covenants With and Without a Sword: SelfGovernance is Possible. American Political Science Review 86(2), 404-417.

Schmitt, P., Swope, K., and Walker, J., 2000. Collective action with incomplete commitment: Experimental evidence. Southern Economic Journal 66(4), 829-854.

Subsecretaría de Pesca (SUBPESCA). 1995. Reglamento sobre Áreas de Manejo y Explotación de Recursos Bentónicos DS No. 355 (Updated April 2010), Ministerio de Economía Fomento y Reconstrucción. http://www.subpesca.cl/portal/615/w3-article-11086.html. Last accessed April 12, 2018.

Torgler, B., 2002. Speaking to theorists and searching for facts: Tax morale and tax compliance in experiments. Journal of Economic Surveys 16(5), 657-683.

Vollan, B., 2008. Socio-ecological explanations for crowding-out effects from economic field experiments in southern Africa. Ecological Economics 67(4), 560-573.

Vélez, M.A., Murphy, J.J., and Stranlund, J.K., 2010. Centralized and decentralized management of local common pool resources in the developing world: experimental evidence from fishing communities in Colombia. Economic Inquiry 48(2), 254-265.

Wilen, J. E., Cancino, J. and Uchida, H. 2012. The economics of territorial use rights fisheries, or turfs. Review of Environmental Economics and Policy 6 (2), 237-257.

Yamagishi, Toshio. 1986. "The provision of a sanctioning system as a public good." Journal of Personality and Social Psychology 51(1): 110-16.

Yamagishi, Toshio. 1988. "Seriousness of social dilemmas and the provision of a sanctioning system." Social Psychology Quarterly 51(1): 32-42. 
Table 1: Theoretical benchmarks

\begin{tabular}{|l|c|c|c|c|c|}
\hline Treatment & Harvests & Poaching & $\begin{array}{c}\text { Terminal } \\
\text { period }\end{array}$ & $\begin{array}{c}\text { Monitoring } \\
\text { costs }\end{array}$ & $\begin{array}{c}\text { Payoffs } \\
\text { (pesos) }\end{array}$ \\
\hline T1. Baseline & & & & & \\
\hline Insider coop harvests & 33.33 & - & 10 & - & 16,665 \\
\hline Insider non-coop harvests & 20 & - & 4 & - & 10,000 \\
\hline & & & & & \\
\hline Outsider coop harvests & 24.67 & - & 10 & - & 12,335 \\
\hline Outsider non-coop harvests & 15 & - & 3 & - & 7,500 \\
\hline
\end{tabular}

\begin{tabular}{|l|c|c|c|c|c|}
\hline T2. Poaching & \multicolumn{5}{l|}{$\begin{array}{l}\text { There is no incentive for the insiders to coordinate their harvests in } \\
\text { this treatment. }\end{array}$} \\
\hline Insider non-coop harvests & 10 & - & 2 & - & 5,000 \\
\hline Outsider non-coop harvests & 25 & 10 & 5 & - & 12,500 \\
\hline
\end{tabular}

\begin{tabular}{|l|c|c|c|c|c|}
\hline T3. External Enforcement & \multicolumn{6}{|l|}{$\begin{array}{l}\text { External monitoring is not sufficient to deter the outsiders in this } \\
\text { treatment. Consequently, equilibrium outcomes are the same as in the } \\
\text { Poaching treatment. }\end{array}$} \\
\hline Insider non-coop harvests & 10 & - & 2 & - & 5,000 \\
\hline Outsider non-coop harvests & 25 & 10 & 5 & - & $10,280^{\dagger}$ \\
\hline
\end{tabular}

\begin{tabular}{|l|c|c|c|c|c|}
\hline T4. Local Enforcement & \multicolumn{4}{|l|}{$\begin{array}{l}\text { It is always beneficial for the insiders to coordinate investments in } \\
\text { monitoring to deter the outsiders in this treatment. All outcomes here } \\
\text { assume that this occurs. If the insiders do not deter the outsiders, then } \\
\text { the benchmarks are the same as in the Poaching treatment. }\end{array}$} \\
\hline Insider coop harvests & 33.33 & - & 10 & 3,750 & $12,915^{\dagger \dagger}$ \\
\hline Insider non-coop harvests & 20 & - & 4 & 1,250 & $8,750^{\dagger \dagger}$ \\
\hline Outsider non-coop harvests & 20 & 5 & 3 & - & 10,000 \\
\hline
\end{tabular}

\begin{tabular}{|l|c|c|c|c|c|}
\hline $\begin{array}{l}\text { T5. External + Local } \\
\text { Enforcement }\end{array}$ & \multicolumn{4}{|l|}{$\begin{array}{l}\text { Outcomes here assume that the insiders deter the outsiders. Thus, } \\
\text { they are the same as in the Local Enforcement treatment, except that } \\
\text { the insiders spend less on monitoring. If the insiders do not deter the } \\
\text { outsiders, then the benchmarks are the same as in the Poaching and } \\
\text { External Enforcement treatments. }\end{array}$} \\
\hline Insider coop harvests & 33.33 & - & 10 & 2,250 & $14,415^{\dagger \dagger}$ \\
\hline Insider non-coop harvests & 20 & - & 4 & 750 & $9,250^{\dagger \dagger}$ \\
\hline Outsider non-coop harvests & 20 & 5 & 3 & - & 10,000 \\
\hline
\end{tabular}

$\dagger$ Expected individual payoffs, which equal harvest payoffs minus expected sanctions.

$\dagger$ Harvest payoff less share of monitoring costs. 
Table 2: Number of subjects and groups by treatment

\begin{tabular}{lcccc}
\hline \multicolumn{1}{c}{ Treatments } & \multicolumn{2}{c}{ TURF members } & \multicolumn{2}{c}{ Students } \\
& Groups & Subjects & Groups & Subjects \\
\hline T1. Baseline & 7 & 42 & 6 & 36 \\
T2. Poaching & 7 & 42 & 7 & 42 \\
T3. External Enforcement & 8 & 48 & 7 & 42 \\
T4. Local Enforcement & 7 & 42 & 7 & 42 \\
T5. External + Local Enforcement & 6 & 36 & 7 & 42 \\
\hline \multicolumn{1}{c}{ Totals } & 35 & 210 & 34 & 204 \\
\hline
\end{tabular}


Table 3. Individual blue harvests in the blue zone (cumulative over all periods)

\begin{tabular}{|c|c|c|c|c|c|}
\hline & \multicolumn{4}{|c|}{ TURF members } & \multirow{2}{*}{$\begin{array}{l}\text { Students } \\
\text { Model } 5\end{array}$} \\
\hline & Model 1 & Model 2 & Model 3 & Model 4 & \\
\hline Constant & $\begin{array}{c}24.53 * * * \\
(1.99)\end{array}$ & $\begin{array}{c}26.72 * * * \\
(2.06)\end{array}$ & $\begin{array}{c}25.64 * * * \\
(2.16)\end{array}$ & $\begin{array}{c}28.10 * * * \\
(2.21)\end{array}$ & $\begin{array}{c}30.18^{* * *} \\
(3.11)\end{array}$ \\
\hline \multicolumn{6}{|l|}{ Treatment } \\
\hline T1. Baseline & omitted & omitted & omitted & omitted & omitted \\
\hline T2. Poaching & $\begin{array}{c}-15.26 * * * \\
(1.75)\end{array}$ & $\begin{array}{c}-18.08 * * * \\
(3.10)\end{array}$ & $\begin{array}{c}-15.37 * * * \\
(1.85)\end{array}$ & $\begin{array}{c}-18.08 * * * \\
(3.18)\end{array}$ & $\begin{array}{c}-17.92 * * * \\
(1.43)\end{array}$ \\
\hline T3. External & $\begin{array}{c}-11.31 * * * \\
(2.68)\end{array}$ & $\begin{array}{c}-10.69 * * * \\
(4.11)\end{array}$ & $\begin{array}{c}-11.14 * * * \\
(2.75)\end{array}$ & $\begin{array}{c}-10.58 * * \\
(4.19)\end{array}$ & $\begin{array}{c}-12.78 * * * \\
(2.33)\end{array}$ \\
\hline T4. Local & $\begin{array}{c}-10.76^{* * *} \\
(2.23)\end{array}$ & $\begin{array}{c}-9.52 * * * \\
(2.87)\end{array}$ & $\begin{array}{c}-10.54 * * * \\
(2.31)\end{array}$ & $\begin{array}{c}-9.54 * * * \\
(2.98)\end{array}$ & $\begin{array}{c}-10.55 * * * \\
(1.97)\end{array}$ \\
\hline T5. Both & $\begin{array}{c}-11.53 * * * \\
(3.09)\end{array}$ & $\begin{array}{c}-9.63 * * \\
(4.51)\end{array}$ & $\begin{array}{c}-11.13 * * * \\
(3.29)\end{array}$ & $\begin{array}{c}-9.42 * * \\
(4.74)\end{array}$ & $\begin{array}{c}-9.34 * * * \\
(2.10)\end{array}$ \\
\hline \multicolumn{6}{|l|}{ Demographics } \\
\hline Male & $\begin{array}{c}1.04 \\
(1.13)\end{array}$ & $\begin{array}{l}1.08 \\
(1.32)\end{array}$ & $\begin{array}{c}1.11 \\
(1.22)\end{array}$ & $\begin{array}{c}1.16 \\
(1.40)\end{array}$ & $\begin{array}{c}0.43 \\
(0.51)\end{array}$ \\
\hline Age (years) & $\begin{array}{l}-0.00 \\
(0.01)\end{array}$ & $\begin{array}{l}-0.00 \\
(0.01)\end{array}$ & $\begin{array}{l}-0.01 \\
(0.01)\end{array}$ & $\begin{array}{l}-0.01 \\
(0.01)\end{array}$ & $\begin{array}{l}-0.04 \\
(0.14)\end{array}$ \\
\hline $\begin{array}{l}\text { Years of formal } \\
\text { schooling }\end{array}$ & $\begin{array}{l}0.12 * \\
(0.07)\end{array}$ & $\begin{array}{c}0.10 \\
(0.08)\end{array}$ & $\begin{array}{c}0.06 \\
(0.06)\end{array}$ & $\begin{array}{c}0.05 \\
(0.07)\end{array}$ & $\begin{array}{c}0.17 \\
(0.17)\end{array}$ \\
\hline $\begin{array}{l}\text { Community fixed } \\
\text { effects }\end{array}$ & No & Yes & No & Yes & $\mathrm{n} / \mathrm{a}$ \\
\hline $\begin{array}{l}\text { Perceptions of } \\
\text { monitoring \& } \\
\text { poaching }\end{array}$ & No & No & Yes & Yes & $\mathrm{n} / \mathrm{a}$ \\
\hline $\mathrm{N}$ & 105 & 105 & 103 & 103 & 105 \\
\hline
\end{tabular}

Hypothesis tests for treatment effects ( $\chi^{2}$ test)

\begin{tabular}{llllll}
\hline T2 $=$ T3 & 0.116 & $0.005^{* * *}$ & $0.088^{*}$ & $0.004 * * *$ & $0.018 * *$ \\
T2 $=$ T4 & $0.020 * *$ & $0.007 * *$ & $0.011^{* *}$ & $0.007 * * *$ & $0.000^{* * *}$ \\
T2 $=$ T5 & 0.194 & $0.024 * *$ & 0.160 & $0.022^{* *}$ & $0.000 * * *$ \\
T3 $=$ T4 & 0.846 & 0.757 & 0.837 & 0.784 & 0.387 \\
T3 $=$ T5 & 0.951 & 0.798 & 0.998 & 0.782 & 0.193 \\
T4 $=$ T5 & 0.810 & 0.963 & 0.861 & 0.963 & 0.598 \\
T3 $=$ T4 = T5 & 0.964 & 0.953 & 0.973 & 0.958 & 0.426 \\
\hline
\end{tabular}

Robust standard errors are clustered at the group-level. Each observation is the cumulative amount harvested by an individual insider over all periods in which the blue zone remained open. 
Table 4. Insiders' individual earnings (cumulative over all periods)

\begin{tabular}{|c|c|c|c|c|c|}
\hline & \multicolumn{4}{|c|}{ TURF members } & \multirow{2}{*}{$\begin{array}{l}\text { Students } \\
\text { Model } 5\end{array}$} \\
\hline & Model 1 & Model 2 & Model 3 & Model 4 & \\
\hline Constant & $\begin{array}{c}12494.19 * * * \\
(987.19)\end{array}$ & $\begin{array}{c}13756.45 * * * \\
(1141.26)\end{array}$ & $\begin{array}{c}12821.06 * * * \\
(1077.85)\end{array}$ & $\begin{array}{c}14224.60 * * * \\
(1180.92)\end{array}$ & $\begin{array}{l}15107.59 * * * \\
(1545.53)\end{array}$ \\
\hline \multicolumn{6}{|l|}{ Treatment } \\
\hline T1. Baseline & omitted & omitted & omitted & omitted & omitted \\
\hline T2. Poaching & $\begin{array}{c}-7661.69 * * * \\
(873.76)\end{array}$ & $\begin{array}{c}-8740.37 * * * \\
(1681.12)\end{array}$ & $\begin{array}{c}-7715.25 * * * \\
(921.49)\end{array}$ & $\begin{array}{c}-8777.38 * * * \\
(1739.05)\end{array}$ & $\begin{array}{l}-8960.25 * * * \\
(716.96)\end{array}$ \\
\hline T3. External & $\begin{array}{c}-5662.80 * * * \\
(1338.47)\end{array}$ & $\begin{array}{c}-4989.18 * * \\
(2161.61)\end{array}$ & $\begin{array}{c}-5577.03 * * * \\
(1370.27)\end{array}$ & $\begin{array}{c}-4971.17 * * \\
(2224.10)\end{array}$ & $\begin{array}{l}-6391.15 * * * \\
(1164.93)\end{array}$ \\
\hline T4. Local & $\begin{array}{c}-6719.62 * * * \\
(901.15)\end{array}$ & $\begin{array}{c}-5638.21 * * * \\
(1560.36)\end{array}$ & $\begin{array}{c}-6590.41 * * * \\
(944.74)\end{array}$ & $\begin{array}{c}-5673.78 * * * \\
(1630.09)\end{array}$ & $\begin{array}{l}-7277.52 * * * \\
(830.98)\end{array}$ \\
\hline T5. Both & $\begin{array}{c}-6958.92 * * * \\
(1690.72)\end{array}$ & $\begin{array}{c}-5854.20 * * \\
(2458.08)\end{array}$ & $\begin{array}{c}-6784.63 * * * \\
(1792.35)\end{array}$ & $\begin{array}{c}-5798.90 * * \\
(2610.45)\end{array}$ & $\begin{array}{l}-6624.40 * * * \\
(1087.56)\end{array}$ \\
\hline \multicolumn{6}{|l|}{ Demographics } \\
\hline Male & $\begin{array}{c}583.76 \\
(536.68)\end{array}$ & $\begin{array}{c}653.68 \\
(630.54)\end{array}$ & $\begin{array}{c}625.11 \\
(583.50)\end{array}$ & $\begin{array}{c}693.94 \\
(672.55)\end{array}$ & $\begin{array}{l}195.09 \\
(250.00)\end{array}$ \\
\hline Age (years) & $\begin{array}{l}-2.38 \\
(6.82)\end{array}$ & $\begin{array}{l}-3.18 \\
(7.24)\end{array}$ & $\begin{array}{l}-5.64 \\
(4.91)\end{array}$ & $\begin{array}{l}-6.41 \\
(5.30)\end{array}$ & $\begin{array}{l}-19.51 \\
(66.92)\end{array}$ \\
\hline $\begin{array}{l}\text { Years of formal } \\
\text { schooling }\end{array}$ & $\begin{array}{c}35.64 \\
(35.16)\end{array}$ & $\begin{array}{c}27.34 \\
(40.10)\end{array}$ & $\begin{array}{c}10.34 \\
(32.46)\end{array}$ & $\begin{array}{c}3.26 \\
(37.09)\end{array}$ & $\begin{array}{l}84.89 \\
(83.53)\end{array}$ \\
\hline $\begin{array}{l}\text { Community fixed } \\
\text { effects }\end{array}$ & No & Yes & No & Yes & $\mathrm{n} / \mathrm{a}$ \\
\hline $\begin{array}{l}\text { Perceptions of } \\
\text { monitoring \& } \\
\text { poaching }\end{array}$ & No & No & Yes & Yes & $\mathrm{n} / \mathrm{a}$ \\
\hline $\mathrm{N}$ & 105 & 105 & 103 & 103 & 102 \\
\hline \multicolumn{6}{|c|}{ Hypothesis tests for treatment effects ( $\chi^{2}$ test) } \\
\hline $\mathrm{T} 2=\mathrm{T} 3$ & 0.109 & $0.004 * * *$ & $0.081^{*}$ & $0.003 * * *$ & $0.018 * *$ \\
\hline $\mathrm{T} 2=\mathrm{T} 4$ & 0.178 & $0.049 * *$ & $0.098 *$ & $0.046 * *$ & $0.016 * *$ \\
\hline $\mathrm{T} 2=\mathrm{T} 5$ & 0.655 & 0.167 & 0.573 & 0.163 & $0.018 * *$ \\
\hline $\mathrm{T} 3=\mathrm{T} 4$ & 0.400 & 0.724 & 0.428 & 0.699 & 0.449 \\
\hline $\mathrm{T} 3=\mathrm{T} 5$ & 0.490 & 0.700 & 0.540 & 0.718 & 0.862 \\
\hline $\mathrm{T} 4=\mathrm{T} 5$ & 0.882 & 0.886 & 0.909 & 0.937 & 0.538 \\
\hline $\mathrm{T} 3=\mathrm{T} 4=\mathrm{T} 5$ & 0.672 & 0.924 & 0.711 & 0.922 & 0.687 \\
\hline
\end{tabular}

Robust standard errors are clustered at the group-level. Each observation is the cumulative amount earned by an individual insider over all periods in which the blue zone remained open. 
Table 5. Individual yellow poaching from the blue zone (cumulative over all periods)

\begin{tabular}{|c|c|c|c|c|c|}
\hline \multirow[b]{3}{*}{ Constant } & \multicolumn{4}{|c|}{ TURF members } & \multirow{2}{*}{$\frac{\text { Students }}{\text { Model } 5}$} \\
\hline & Model 1 & Model 2 & Model 3 & Model 4 & \\
\hline & $\begin{array}{c}13.79 * * \\
(6.16)\end{array}$ & $\begin{array}{l}10.56 \\
(8.62)\end{array}$ & $\begin{array}{c}17.63 * * \\
(7.68)\end{array}$ & $\begin{array}{c}15.75 \\
(11.34)\end{array}$ & $\begin{array}{c}8.19 \\
(8.45)\end{array}$ \\
\hline \multicolumn{6}{|l|}{ Treatments } \\
\hline $\begin{array}{l}\text { T1. Baseline } \\
\text { T2. Poaching }\end{array}$ & $\begin{array}{c}\mathrm{n} / \mathrm{a} \\
\text { omitted }\end{array}$ & $\begin{array}{c}\mathrm{n} / \mathrm{a} \\
\text { omitted }\end{array}$ & $\begin{array}{c}\mathrm{n} / \mathrm{a} \\
\text { omitted }\end{array}$ & $\begin{array}{c}\mathrm{n} / \mathrm{a} \\
\text { omitted }\end{array}$ & $\begin{array}{c}\mathrm{n} / \mathrm{a} \\
\text { omitted }\end{array}$ \\
\hline T3. External & $\begin{array}{c}-4.20 * * \\
(2.00)\end{array}$ & $\begin{array}{c}-5.25 * * \\
(2.40)\end{array}$ & $\begin{array}{c}-4.98 * * * \\
(1.81)\end{array}$ & $\begin{array}{c}-7.54 * * * \\
(2.28)\end{array}$ & $\begin{array}{l}-2.29 \\
(2.08)\end{array}$ \\
\hline T4. Local & $\begin{array}{c}-4.40 * * * \\
(1.47)\end{array}$ & $\begin{array}{l}-4.03 \\
(3.75)\end{array}$ & $\begin{array}{c}-4.83 * * * \\
(1.70)\end{array}$ & $\begin{array}{l}-6.28 * \\
(3.46)\end{array}$ & $\begin{array}{c}-3.76 * * * \\
(1.26)\end{array}$ \\
\hline T5. Both & $\begin{array}{l}-3.34 \\
(2.15)\end{array}$ & $\begin{array}{l}-3.96 \\
(2.53)\end{array}$ & $\begin{array}{l}-5.06 \\
(3.41)\end{array}$ & $\begin{array}{l}-8.97 * \\
(4.72)\end{array}$ & $\begin{array}{c}-4.21 * * \\
(1.76)\end{array}$ \\
\hline \multicolumn{6}{|l|}{ Demographics } \\
\hline Male & $\begin{array}{l}4.87 * * \\
(2.25)\end{array}$ & $\begin{array}{l}6.34 * * \\
(2.68)\end{array}$ & $\begin{array}{l}5.55^{* *} \\
(2.38)\end{array}$ & $\begin{array}{c}7.49 * * * \\
(2.51)\end{array}$ & $\begin{array}{c}0.31 \\
(1.53)\end{array}$ \\
\hline Age (years) & $\begin{array}{l}-0.05 \\
(0.09)\end{array}$ & $\begin{array}{c}0.01 \\
(0.11)\end{array}$ & $\begin{array}{l}-0.08 \\
(0.10)\end{array}$ & $\begin{array}{c}0.01 \\
(0.12)\end{array}$ & $\begin{array}{c}0.13 \\
(0.40)\end{array}$ \\
\hline $\begin{array}{l}\text { Years of formal } \\
\text { schooling }\end{array}$ & $\begin{array}{l}-0.27 \\
(0.35)\end{array}$ & $\begin{array}{l}-0.11 \\
(0.52)\end{array}$ & $\begin{array}{l}-0.39 \\
(0.42)\end{array}$ & $\begin{array}{c}0.00 \\
(0.58)\end{array}$ & $\begin{array}{l}-0.48 \\
(0.57)\end{array}$ \\
\hline $\begin{array}{l}\text { Community fixed } \\
\text { effects }\end{array}$ & No & Yes & No & Yes & $\mathrm{n} / \mathrm{a}$ \\
\hline $\begin{array}{l}\text { Perceptions of } \\
\text { monitoring \& } \\
\text { poaching }\end{array}$ & No & No & Yes & Yes & $\mathrm{n} / \mathrm{a}$ \\
\hline $\mathrm{N}$ & 83 & 83 & 81 & 81 & 83 \\
\hline
\end{tabular}

Hypothesis tests for treatment effects $\left(\chi^{2}\right.$ test $)$

\begin{tabular}{llllll}
\hline $\mathrm{T} 2=\mathrm{T} 3$ & $0.036 * *$ & $0.029 * *$ & $0.006 * * *$ & $0.001 * * *$ & 0.271 \\
$\mathrm{~T} 2=\mathrm{T} 4$ & $0.003 * * *$ & 0.283 & $0.004 * * *$ & $0.070 *$ & $0.003 * * *$ \\
$\mathrm{~T} 2=\mathrm{T} 5$ & 0.121 & 0.118 & 0.138 & $0.057 *$ & $0.017 * *$ \\
$\mathrm{~T} 3=\mathrm{T} 4$ & 0.914 & 0.684 & 0.935 & 0.634 & 0.452 \\
$\mathrm{~T} 3=\mathrm{T} 5$ & 0.694 & 0.470 & 0.979 & 0.698 & 0.398 \\
$\mathrm{~T} 4=\mathrm{T} 5$ & 0.568 & 0.980 & 0.931 & 0.404 & 0.728 \\
$\mathrm{~T} 3=\mathrm{T} 4=\mathrm{T} 5$ & 0.847 & 0.767 & 0.994 & 0.675 & 0.696 \\
\hline
\end{tabular}

Robust standard errors are clustered at the group-level. Each observation is the cumulative amount poached by an individual outsider over all periods in which the blue zone remained open. 
Table 6. Average individual local monitoring investment per round

\begin{tabular}{|c|c|c|c|c|c|}
\hline & \multicolumn{4}{|c|}{ TURF members } & \multirow{2}{*}{$\begin{array}{l}\text { Students } \\
\text { Model } 5\end{array}$} \\
\hline & Model 1 & Model 2 & Model 3 & Model 4 & \\
\hline Constant & $\begin{array}{c}0.29 \\
(0.22)\end{array}$ & $\begin{array}{l}-0.09 \\
(0.41)\end{array}$ & $\begin{array}{l}0.47 * \\
(0.25)\end{array}$ & $\begin{array}{c}0.09 \\
(0.45)\end{array}$ & $\begin{array}{c}0.77 * * * \\
(0.12)\end{array}$ \\
\hline \multicolumn{6}{|l|}{ Treatments } \\
\hline $\begin{array}{l}\text { T4. Local } \\
\text { T5. Both }\end{array}$ & $\begin{array}{c}\text { omitted } \\
-0.07 \\
(0.20)\end{array}$ & $\begin{array}{c}\text { omitted } \\
0.11 \\
(0.30)\end{array}$ & $\begin{array}{c}\text { omitted } \\
-0.05 \\
(0.21)\end{array}$ & $\begin{array}{c}\text { omitted } \\
0.11 \\
(0.31)\end{array}$ & $\begin{array}{c}\text { omitted } \\
-0.02 \\
(0.13)\end{array}$ \\
\hline \multicolumn{6}{|l|}{ Demographics } \\
\hline Male & $\begin{array}{l}-0.07 \\
(0.10)\end{array}$ & $\begin{array}{l}-0.15 \\
(0.10)\end{array}$ & $\begin{array}{l}-0.10 \\
(0.09)\end{array}$ & $\begin{array}{l}-0.16^{*} \\
(0.10)\end{array}$ & $\begin{array}{c}0.01 \\
(0.01)\end{array}$ \\
\hline Age (years) & $\begin{array}{c}0.00 \\
(0.00)\end{array}$ & $\begin{array}{c}0.00 \\
(0.00)\end{array}$ & $\begin{array}{c}0.00 \\
(0.00)\end{array}$ & $\begin{array}{c}0.00 \\
(0.00)\end{array}$ & $\begin{array}{c}0.00 \\
(0.00)\end{array}$ \\
\hline $\begin{array}{l}\text { Years of formal } \\
\text { schooling }\end{array}$ & $\begin{array}{c}0.02 * * * \\
(0.01)\end{array}$ & $\begin{array}{l}0.02 * * * \\
(0.01)\end{array}$ & $\begin{array}{c}0.02 * * \\
(0.01)\end{array}$ & $\begin{array}{c}0.02 * * \\
(0.01)\end{array}$ & $\begin{array}{c}0.00 \\
(0.01)\end{array}$ \\
\hline Community fixed effects & No & Yes & No & Yes & $\mathrm{n} / \mathrm{a}$ \\
\hline $\begin{array}{l}\text { Perceptions of } \\
\text { monitoring \& poaching }\end{array}$ & No & No & Yes & Yes & $\mathrm{n} / \mathrm{a}$ \\
\hline $\mathrm{N}$ & 39 & 39 & 38 & 38 & 42 \\
\hline
\end{tabular}

Robust standard errors are clustered at the group-level. Each observation is the mean amount contributed to local monitoring by an individual insider over all periods in which the blue zone remained open. 
Figure 1. Mean ending biomass in blue zone

T1. Baseline

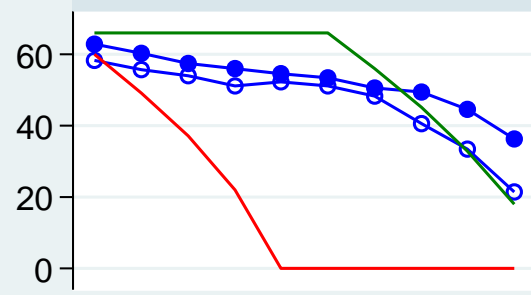

T4. Local

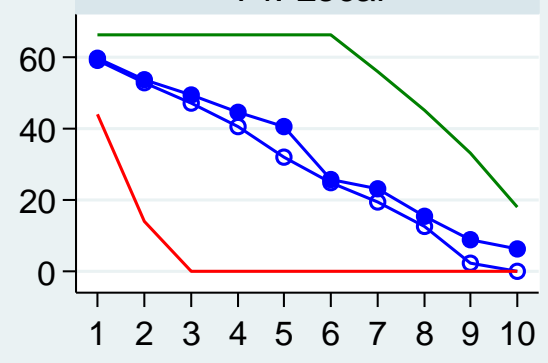

T2. Poaching

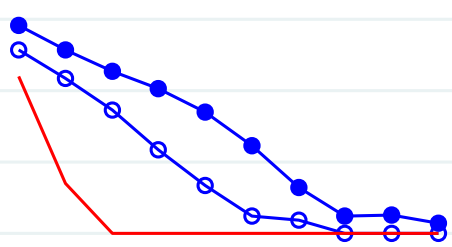

T5. Both

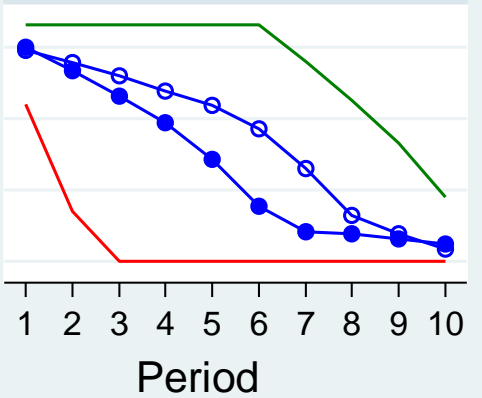

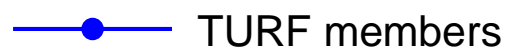

Cooperative
T3. External

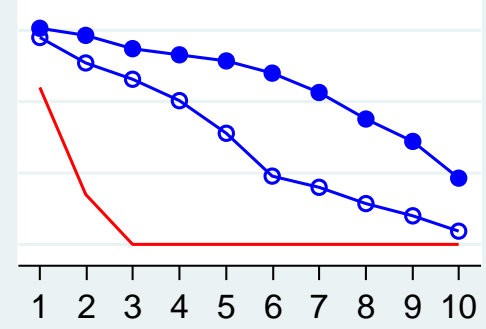

Biomass $=0$ if zone was closed 
Figure 2. Blue group mean terminal period

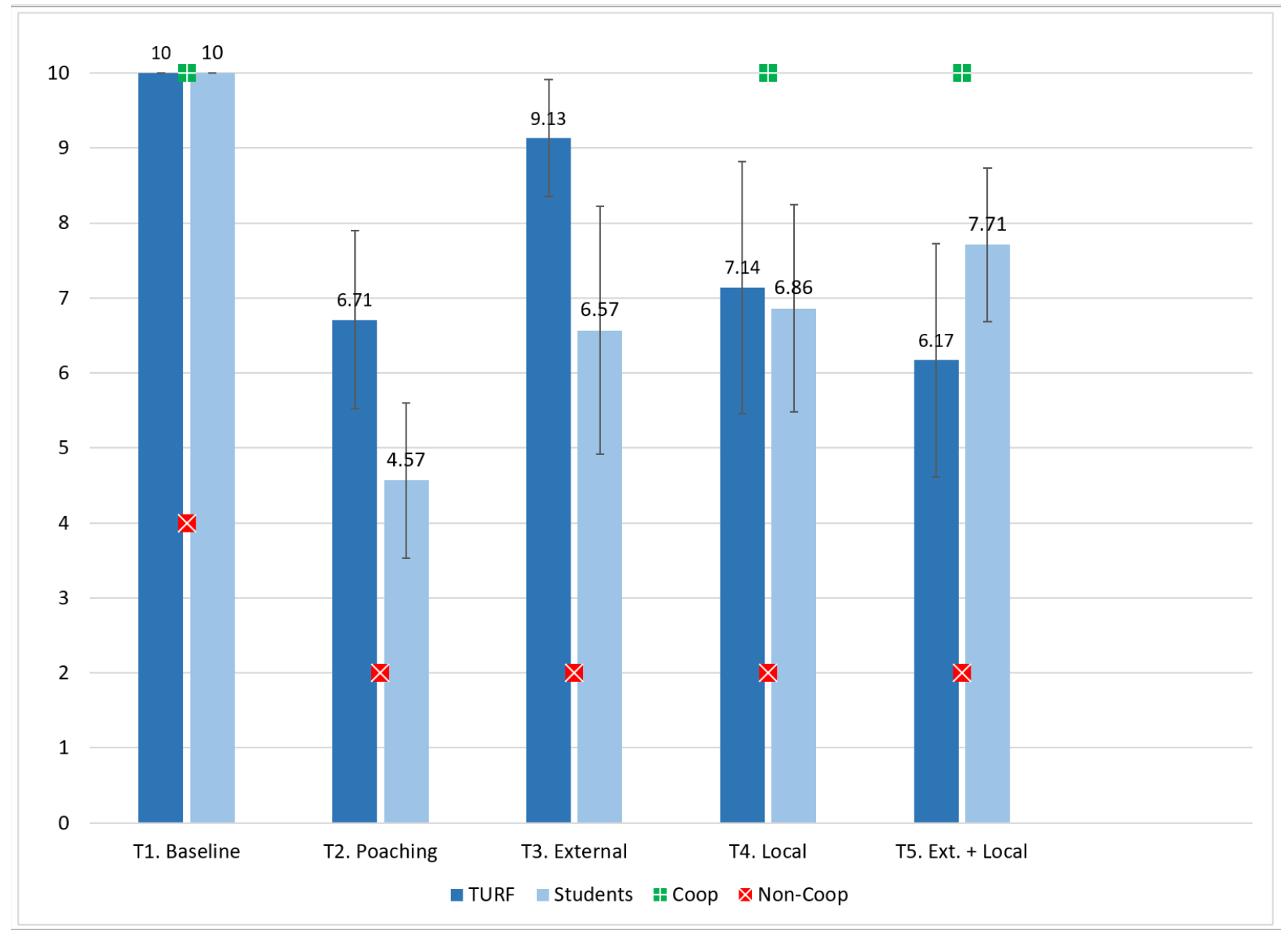

Error bars show 95\% confidence intervals. The squares denoted Co-op and Non-coop reference the cooperative and non-cooperative outcomes. 
Figure 3: Blue group mean individual cumulative harvest

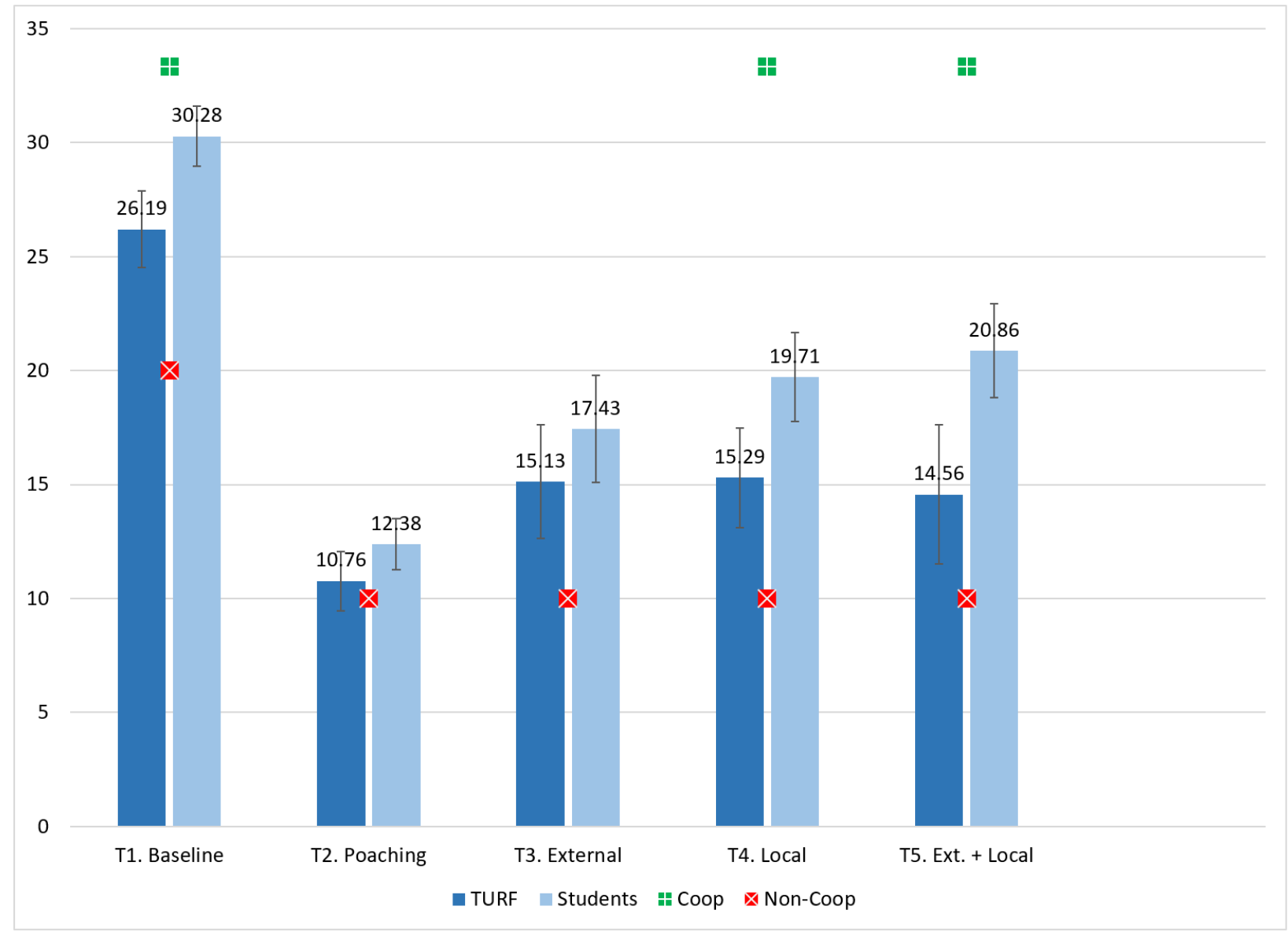

Error bars show $95 \%$ confidence intervals. The squares denoted Coop and Non-coop reference the cooperative and non-cooperative outcomes. 
Figure 4: Blue group mean individual cumulative earnings

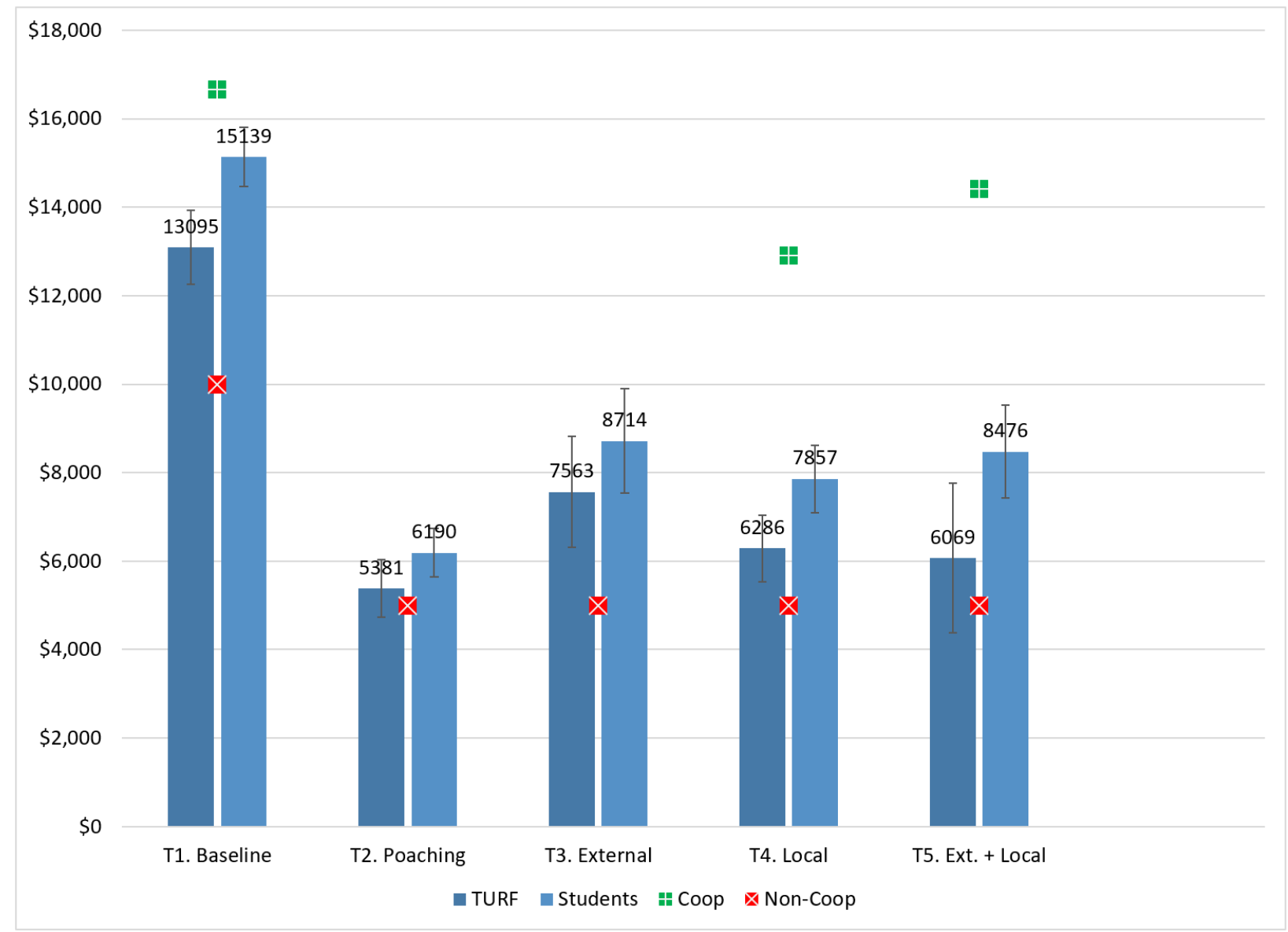

Error bars show 95\% confidence intervals. The squares denoted Coop and Non-coop reference the cooperative and non-cooperative outcomes. 
Figure 5: Yellow group mean individual cumulative poaching from blue zone

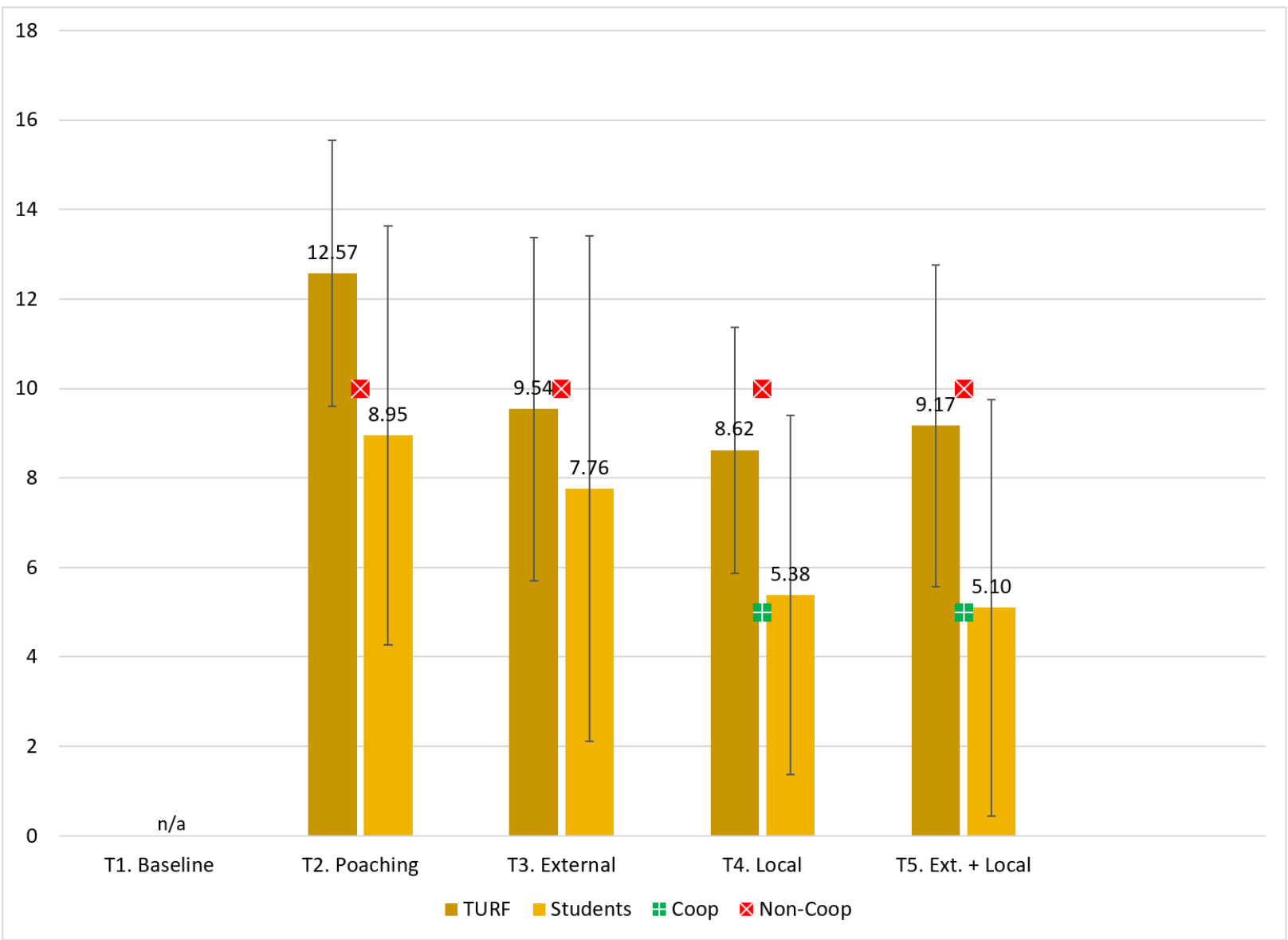

Error bars show 95\% confidence intervals. The squares denoted Coop and Non-coop reference the cooperative and non-cooperative outcomes. 
Figure 6. Monitoring probabilities over time

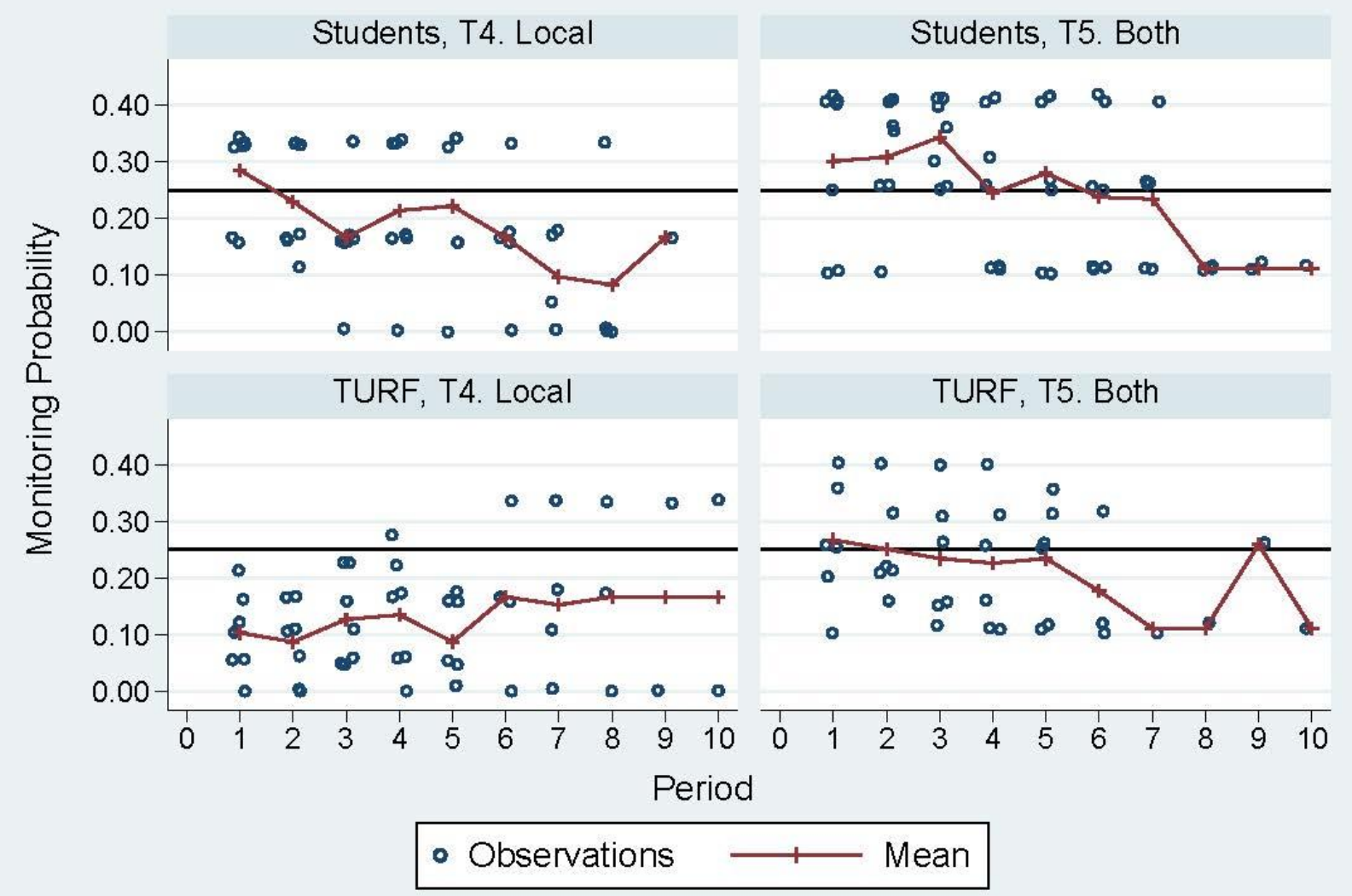

Figure only includes data from active groups. Note that in the later rounds, the number of active groups declines. The horizontal line at 0.25 represents the minimum probability needed to fully deter poaching. 


\section{Online Appendix}

\section{Demonstrations of theoretical benchmarks in Table 1}

In this section we demonstrate the theoretical benchmarks in Table 1.

Recall the fundamentals of stocks and harvesters. The initial insider stock is 70 units, and the stock is 'depleted' if it falls below the critical level of 30 units. The initial outsider stock is 45 units, and the stock is depleted if it falls below 15 units. The growth rate is 10\% (in discrete units) in both zones. There are three harvesters in each zone, and harvest capacity is five units per harvester per period. There are 10 periods.

\section{T1. Baseline}

In this treatment there is no encroachment on the inside zone from the outsiders, so we have two separate dynamic linear common pool resource problems. We present cooperative and noncooperative harvest benchmarks for each zone. By 'cooperative' we mean that harvesters in a zone coordinate their harvest strategies to maximize the joint payoffs of the group. By 'noncooperative' we mean that harvesters are not able to coordinate their harvest choices so they choose pure Nash strategies.

\section{Cooperative benchmarks}

Given the discreteness of growth, the cooperative harvest strategy in each zone is to first draw the resource down in the first period to the stock that produces maximum sustained growth. Then, at a later period individuals harvest to capacity so that the stock falls below the critical threshold at the end of the last period.

\begin{tabular}{|l|l|l|}
\hline \multicolumn{3}{|l|}{ Insider cooperative harvest of inside zone } \\
\hline Period & $\begin{array}{l}\text { Stock at start of } \\
\text { period }\end{array}$ & $\begin{array}{l}\text { Aggregate harvest } \\
\text { during period }\end{array}$ \\
\hline 1 & 70 & 10 \\
\hline 2 & $60+6=66$ & 6 \\
\hline 3 & $60+6=66$ & 6 \\
\hline 4 & $60+6=66$ & 6 \\
\hline 5 & $60+6=66$ & 6 \\
\hline 6 & $60+6=66$ & 6 \\
\hline 7 & $60+6=66$ & 15 \\
\hline 8 & $51+5=56$ & 15 \\
\hline 9 & $41+4=45$ & 15 \\
\hline 10 & $30+3=33$ & 15 \\
\hline & $\begin{array}{l}18 \text { units at end of } \\
\text { round so stock is } \\
\text { depleted }\end{array}$ & Total $=100$ \\
\hline
\end{tabular}




\begin{tabular}{|l|l|l|}
\hline \multicolumn{3}{|l|}{ Outsider cooperative harvest of outside zone } \\
\hline Period & $\begin{array}{l}\text { Stock at start of } \\
\text { period }\end{array}$ & $\begin{array}{l}\text { Aggregate harvest } \\
\text { during period }\end{array}$ \\
\hline 1 & 45 & 5 \\
\hline 2 & $40+4=44$ & 4 \\
\hline 3 & $40+4=44$ & 4 \\
\hline 4 & $40+4=44$ & 4 \\
\hline 5 & $40+4=44$ & 4 \\
\hline 6 & $40+4=44$ & 4 \\
\hline 7 & $40+4=44$ & 4 \\
\hline 8 & $40+4=44$ & 15 \\
\hline 9 & $29+2=31$ & 15 \\
\hline 10 & $16+1=17$ & 15 \\
\hline & $\begin{array}{l}2 \text { units at end of } \\
\text { round so stock is } \\
\text { depleted }\end{array}$ & Total $=74$ \\
\hline
\end{tabular}

\section{Non-cooperative benchmarks}

If group members are not able to coordinate their harvests, then individually they have no incentive to conserve the resource. Then, because of the linear benefit of harvests, each individual harvests at capacity in every period until the zone is depleted.

\begin{tabular}{|l|l|l|}
\hline \multicolumn{3}{|l|}{ Insider non-cooperative harvest of inside zone } \\
\hline Period & $\begin{array}{l}\text { Stock at start } \\
\text { of period }\end{array}$ & $\begin{array}{l}\text { Aggregate harvest } \\
\text { during period }\end{array}$ \\
\hline 1 & 70 & 15 \\
\hline 2 & $55+5=60$ & 15 \\
\hline 3 & $45+4=49$ & 15 \\
\hline 4 & $34+3=37$ & 15 \\
\hline 5 & $\begin{array}{l}22, \text { stock is } \\
\text { depleted }\end{array}$ & Total $=60$ \\
\hline \multicolumn{2}{|l|}{ Stock is depleted after 4 rounds. } \\
\hline
\end{tabular}

\begin{tabular}{|l|l|l|}
\hline \multicolumn{3}{|l|}{$\begin{array}{l}\text { Outsider non-cooperative harvest of outsider } \\
\text { zone }\end{array}$} \\
\hline Period & $\begin{array}{l}\text { Stock at start } \\
\text { of period }\end{array}$ & $\begin{array}{l}\text { Aggregate harvest } \\
\text { during period }\end{array}$ \\
\hline 1 & 45 & 15 \\
\hline 2 & $30+3=33$ & 15 \\
\hline 3 & $18+1=19$ & 15 \\
\hline 4 & $\begin{array}{l}4, \text { stock is } \\
\text { depleted }\end{array}$ & Total $=45$ \\
\hline \multicolumn{3}{|l|}{ Stock is depleted in 3 rounds. } \\
\hline
\end{tabular}




\section{T2. Poaching}

In this treatment the outsiders can freely poach from the insider zone. In this case there is no incentive for the insiders to attempt to conserve the resource. Therefore, they harvest at capacity in their zone until the stock is depleted. The outsiders also harvest at capacity in every round, but they poach in the insider zone until it is depleted, and then they harvest in the outside zone until it is depleted.

\begin{tabular}{|c|c|c|c|c|}
\hline \multirow[b]{2}{*}{ Period } & \multicolumn{2}{|c|}{$\begin{array}{l}\text { Insider non-cooperative harvest of inside } \\
\text { zone }\end{array}$} & \multicolumn{2}{|c|}{$\begin{array}{l}\text { Outsider non-cooperative harvest of } \\
\text { outside zone }\end{array}$} \\
\hline & $\begin{array}{l}\text { Inside stock at start } \\
\text { of period }\end{array}$ & $\begin{array}{l}\text { Aggregate harvest } \\
\text { in inside zone } \\
\text { during period }\end{array}$ & $\begin{array}{l}\text { Outside stock at } \\
\text { start of period }\end{array}$ & $\begin{array}{l}\text { Aggregate harvest } \\
\text { in outside zone } \\
\text { during period }\end{array}$ \\
\hline 1 & 70 & $15+15$ (outsiders) & 45 & 0 \\
\hline 2 & $40+4=44$ & $15+15$ (outsiders) & 45 & 0 \\
\hline 3 & $\begin{array}{l}14 \text { - stock is } \\
\text { depleted }\end{array}$ & $\begin{array}{l}\text { Total harvest by } \\
\text { insiders }=30\end{array}$ & 45 & 15 \\
\hline 4 & & & $30+3=33$ & 15 \\
\hline 5 & & & $18+1=19$ & 15 \\
\hline \multirow[t]{2}{*}{6} & & & $\begin{array}{l}4, \text { stock is } \\
\text { depleted }\end{array}$ & $\begin{array}{l}\text { Total = } 75 \text { (30 in } \\
\text { inside zone, } 45 \text { in } \\
\text { outside zone) }\end{array}$ \\
\hline & \multicolumn{2}{|c|}{$\begin{array}{l}\text { Inside zone is depleted after } 2 \text { periods. } \\
\text { Payoff per insider is } 10 \text { units. }\end{array}$} & \multicolumn{2}{|c|}{$\begin{array}{l}\text { Outside zone is depleted after } 5 \text { periods. } \\
\text { Outsiders harvest an extra } 30 \text { units in } \\
\text { the first two periods in the inside zone, } \\
\text { then move to their zone in the } 3^{\text {rd }} \text { period } \\
\text { and harvest additional } 45 \text { units over the } \\
\text { next three periods. }\end{array}$} \\
\hline
\end{tabular}

To show that it is better for the outsiders to harvest in the inside zone and then in the outside zone instead of the reverse, the following is a demonstration of non-cooperative harvests if the outsiders deplete their zone first before moving to the inside zone. Notice that total harvests of the outsiders are lower with this strategy.

\begin{tabular}{|l|l|l|l|l|}
\cline { 2 - 5 } \multicolumn{2}{c|}{} & \multicolumn{2}{l|}{$\begin{array}{l}\text { Insider non-cooperative harvest of } \\
\text { inside zone }\end{array}$} & \multicolumn{2}{l|}{$\begin{array}{l}\text { Outsider non-cooperative harvest of } \\
\text { outside zone }\end{array}$} \\
\hline Period & $\begin{array}{l}\text { Inside stock at } \\
\text { start of period }\end{array}$ & $\begin{array}{l}\text { Aggregate } \\
\text { harvest in inside } \\
\text { zone during } \\
\text { period }\end{array}$ & $\begin{array}{l}\text { Outside stock at } \\
\text { start of period }\end{array}$ & $\begin{array}{l}\text { Aggregate } \\
\text { harvest in } \\
\text { outside zone } \\
\text { during period }\end{array}$ \\
\hline 1 & 70 & 15 & 45 & 15 \\
\hline 2 & $55+5=60$ & 15 & $30+3=33$ & 15 \\
\hline 3 & $45+4=49$ & 15 & $18+1=19$ & 15 \\
\hline 4 & $34+3=37$ & $\begin{array}{l}15+15 \\
\text { (outsiders) }\end{array}$ & $\begin{array}{l}\text { 4-stock is } \\
\text { depleted }\end{array}$ & $\begin{array}{l}\text { Outsiders move } \\
\text { harvest to inside } \\
\text { zone }\end{array}$ \\
\hline
\end{tabular}




\begin{tabular}{|l|l|l|l|l|}
\hline 5 & $\begin{array}{l}\text { 7-stock is } \\
\text { depleted }\end{array}$ & $\begin{array}{l}\text { Total harvest by } \\
\text { insiders }=60\end{array}$ & $\begin{array}{l}\text { Total harvest by } \\
\text { outsiders }=60\end{array}$ \\
\hline & $\begin{array}{l}\text { Inside zone is depleted after } 4 \\
\text { periods. }\end{array}$ & $\begin{array}{l}\text { Outside zone is depleted after } 3 \\
\text { periods. Outsiders harvest an extra } \\
15 \text { units in the inside zone in the } 4^{\text {th }} \\
\text { period. }\end{array}$ \\
\cline { 2 - 4 }
\end{tabular}

\section{T3. External enforcement}

In this treatment the government monitors for poaching so that the probability an individual outsider is audited is $11.1 \%$. Since the unit poaching sanction is 2000 pesos, the expected sanction is 222 pesos, which is significantly below the 500 peso unit value of harvests. Thus, the outsiders are not deterred by the enforcement strategy and the harvest benchmarks in this treatment are the same as in T2. Payoffs for the insiders are the same as in T2, but outsider expected payoffs are reduced by the amount of the expected sanctions.

\section{T4. Local enforcement}

Whether the insiders coordinate their harvest to maximize their joint payoffs or not, they are better off deterring the outsiders from poaching. Hence, in Table 1 we present benchmarks for when the insiders coordinate their harvests and when they do not, given that the outsiders are deterred.

Note in the following that there are 33 units of the inside stock available at the start of period ten. Hence, both groups can harvest at capacity in that period. There is no incentive for the insiders to deter poaching in the last period - they harvest to capacity and any remaining stock has no value after the final period is over. Since the outsiders know that insiders will not try to defend their zone in the last period, they will poach at capacity in the last period.

\section{Cooperative benchmark}

\begin{tabular}{|l|l|l|l|l|}
\cline { 2 - 5 } \multicolumn{1}{c|}{} & \multicolumn{3}{l|}{$\begin{array}{l}\text { Insider cooperative harvest of inside } \\
\text { zone }\end{array}$} & \multicolumn{2}{l|}{$\begin{array}{l}\text { Outsider non-cooperative harvest } \\
\text { of outside zone }\end{array}$} \\
\hline Period & $\begin{array}{l}\text { Inside stock at } \\
\text { start of period }\end{array}$ & $\begin{array}{l}\text { Aggregate harvest } \\
\text { in inside zone } \\
\text { during period }\end{array}$ & $\begin{array}{l}\text { Outside stock } \\
\text { at start of } \\
\text { period }\end{array}$ & $\begin{array}{l}\text { Aggregate } \\
\text { harvest in } \\
\text { outside zone } \\
\text { during period }\end{array}$ \\
\hline 1 & 70 & 10 & 45 & 15 \\
\hline 2 & $60+6=66$ & 6 & $30+3=33$ & 15 \\
\hline 3 & $60+6=66$ & 6 & $18+1=19$ & 15 \\
\hline 4 & $60+6=66$ & 6 & $\begin{array}{l}4 \text {-stock is } \\
\text { depleted }\end{array}$ & \\
\hline 5 & $60+6=66$ & 6 & & \\
\hline 6 & $60+6=66$ & 6 & & \\
\hline 7 & $60+6=66$ & 15 & & \\
\hline 8 & $51+5=56$ & 15 & & \\
\hline 9 & $41+4=45$ & 15 & & \\
\hline
\end{tabular}




\begin{tabular}{|l|l|l|l|l|}
\hline 10 & $30+3=33$ & $15+15$ (outsiders) & & \\
\hline & $\begin{array}{l}3 \text { units at end of } \\
\text { round so stock is } \\
\text { depleted. }\end{array}$ & $\begin{array}{l}\text { Total harvest= } \\
100 .\end{array}$ & $\begin{array}{l}\text { Total harvest by } \\
\text { outsiders }=60, \\
\text { 45 in their zone } \\
\text { and 15 in the } \\
\text { insider zone. }\end{array}$ \\
\hline
\end{tabular}

The non-cooperative benchmark is below. Here the insiders are not able to coordinate their harvests, but they can coordinate their investment in monitoring to deter the outsiders. Note that insiders harvest to capacity in the fourth round, even if they don't deter the outsiders, and the stock is depleted in this round whether the outsiders are deterred or not. Therefore, the insiders will not defend their resource in the fourth period

\section{Non-cooperative benchmark}

\begin{tabular}{|l|l|l|l|l|}
\cline { 2 - 5 } \multicolumn{2}{c|}{} & \multicolumn{2}{l|}{$\begin{array}{l}\text { Insider cooperative harvest of inside } \\
\text { zone }\end{array}$} & $\begin{array}{l}\text { Outsider non-cooperative harvest of } \\
\text { outside zone }\end{array}$ \\
\hline Period & $\begin{array}{l}\text { Inside stock at } \\
\text { start of period }\end{array}$ & $\begin{array}{l}\text { Aggregate } \\
\text { harvest in inside } \\
\text { zone during } \\
\text { period }\end{array}$ & $\begin{array}{l}\text { Outside stock at } \\
\text { start of period }\end{array}$ & $\begin{array}{l}\text { Aggregate } \\
\text { harvest in } \\
\text { outside zone } \\
\text { during period }\end{array}$ \\
\hline 1 & 70 & 15 & 45 & 15 \\
\hline 2 & $55+5=60$ & 15 & $30+3=33$ & 15 \\
\hline 3 & $45+4=49$ & 15 & $18+1=19$ & 15 \\
\hline 4 & $34+3=37$ & $15+15$ outsiders & $\begin{array}{l}4 \text {-outside stock } \\
\text { is depleted }\end{array}$ & \\
\hline 5 & $\begin{array}{l}22-\text {-stock is } \\
\text { depleted }\end{array}$ & $\begin{array}{l}\text { Total harvest= } \\
60 .\end{array}$ & & $\begin{array}{l}\text { Total harvest by } \\
\text { outsiders }=60, \\
\text { 45 in their zone } \\
\text { and 15 in the } \\
\text { insider zone. }\end{array}$ \\
\hline
\end{tabular}

T5. Combined external and local enforcement The harvest benchmarks in this treatment are the same as in T4. All that is different is that the insiders spend less to deter the outsiders. 


\section{Description of TURFs and Location}

Table A.2-1 Description of the unions that participated in the experiment

\begin{tabular}{|c|c|c|c|c|c|c|}
\hline $\begin{array}{l}\text { Commune/ } \\
\text { Municipality }\end{array}$ & Community & Type & $\begin{array}{l}\mathrm{N}^{\circ} \text { of unions in } \\
\text { the community }\end{array}$ & Unions that participated in the experiment & $\begin{array}{c}\mathrm{N}^{\circ} \text { of } \\
\text { members }\end{array}$ & $\begin{array}{l}\text { Size } \\
\text { (ha) }\end{array}$ \\
\hline Tome & Coliumo & Rural & 3 & $\begin{array}{l}\text { - S.T.I. PESCADORAS ARTESANALES, } \\
\text { RECOLECTORAS DE ALGAS CALETA } \\
\text { COLIUMO }\end{array}$ & 30 & 2.49 \\
\hline \multirow[t]{5}{*}{ Penco } & Cerro Verde & Urban & 4 & - $\quad$ SINDICATO CARLOS CONDELL & 23 & 21.47 \\
\hline & & & & - SINDICATO CERRO VERDE & 41 & 76.14 \\
\hline & & & & - $\quad$ SINDICATO PUNTA LISA & 40 & 21.47 \\
\hline & Lirquen & Urban & 2 & $\begin{array}{l}\text { S.T.I. BUZOS MARISCADORES DE } \\
\text { LIRQUEN }\end{array}$ & 35 & 45.94 \\
\hline & & & & $\begin{array}{l}\text { - S.T.I. PESCADORES DE LAS CALETAS } \\
\text { CERRO VERDE PENCO Y LIRQUEN }\end{array}$ & 28 & 86.39 \\
\hline \multirow[t]{2}{*}{ Hualpen } & Chome & Rural & 3 & $\begin{array}{l}\text { - S.T.I. DE LA PESCA ARTESANAL DE } \\
\text { LA PENINSULA HUALPEN }\end{array}$ & 26 & 101.07 \\
\hline & Perone & Rural & 1 & $\begin{array}{l}\text { - S.T.I. PESCADORES ARTESANALES Y } \\
\text { ACTIVIDADES CONEXAS DE LA } \\
\text { CALETA PERONE }\end{array}$ & 28 & 16.8 \\
\hline Coronel & Maule & Urban & 1 & $\begin{array}{l}\text { S.T.I. DE LA PESCA ARTESANAL, } \\
\text { BUZOS MARISCADORES, } \\
\text { AYUDANTES DE BUZOS Y } \\
\text { ACTIVIDADES CONEXAS DE CALETA } \\
\text { MAULE }\end{array}$ & 27 & 59.9 \\
\hline Lota & Lota Bajo & Urban & 1 & - $\quad$ SINDICATO SIPESCA & 62 & 42.02 \\
\hline Arauco & Llico & Rural & 1 & $\begin{array}{l}\text { S.T.I. DE LA PESCA ARTESANAL, } \\
\text { BUZOS MARISCADORES Y } \\
\text { ACTIVIDADES CONEXAS DE LA } \\
\text { CALETA LLICO }\end{array}$ & 50 & 91.73 \\
\hline
\end{tabular}




\begin{tabular}{|c|c|c|c|c|c|}
\hline Punta Lavapie & Rural & 2 & $\begin{array}{l}\text { - } \quad \text { SINDICATO PUERTO VIEJO PUNTA } \\
\text { LAVAPIÉ } \\
\text { - } \quad \text { STI PUERTO NUEVO PUNTA LAVAPIÉ }\end{array}$ & 40 & 11.48 \\
\hline Arauco & Urban & 1 & - S.T.I. DE CALETA ARAUCO & 37 & 28.06 \\
\hline Rumena & Rural & 3 & $\begin{array}{l}\text { - S.T.I. PESCADORES ARTESANALES Y } \\
\text { ACTIVIDADES CONEXAS DE LA } \\
\text { CALETA RUMENA }\end{array}$ & 72 & 74.48 \\
\hline El Piure & Rural & 1 & $\begin{array}{l}\text { - S.T.I. PESC ARTES BUZOS MARISC Y } \\
\text { ALG ACUIC Y ACT CONEX LOS } \\
\text { PIURES }\end{array}$ & 34 & 271.86 \\
\hline
\end{tabular}

(Number of unions in the community and size of the BRMAs (ha.) were obtained from SERNAPESCA (publicly available in their website http://www.sernapesca.cl/index.php?option=com_remository\&Itemid=246\&func=startdown\&id=912, last accessed 14 April, 2018). Number of unions' members were provided by Project FIPA-2016-57, Quiroga, M. et al. (2017). "Determinación del beneficio potencial de la implementación de la ley de bonificación de algas en el sector acuicultor de las regiones del Biobío y Los Lagos". Pre-informe final." 


\subsection{Fishing communities visited}

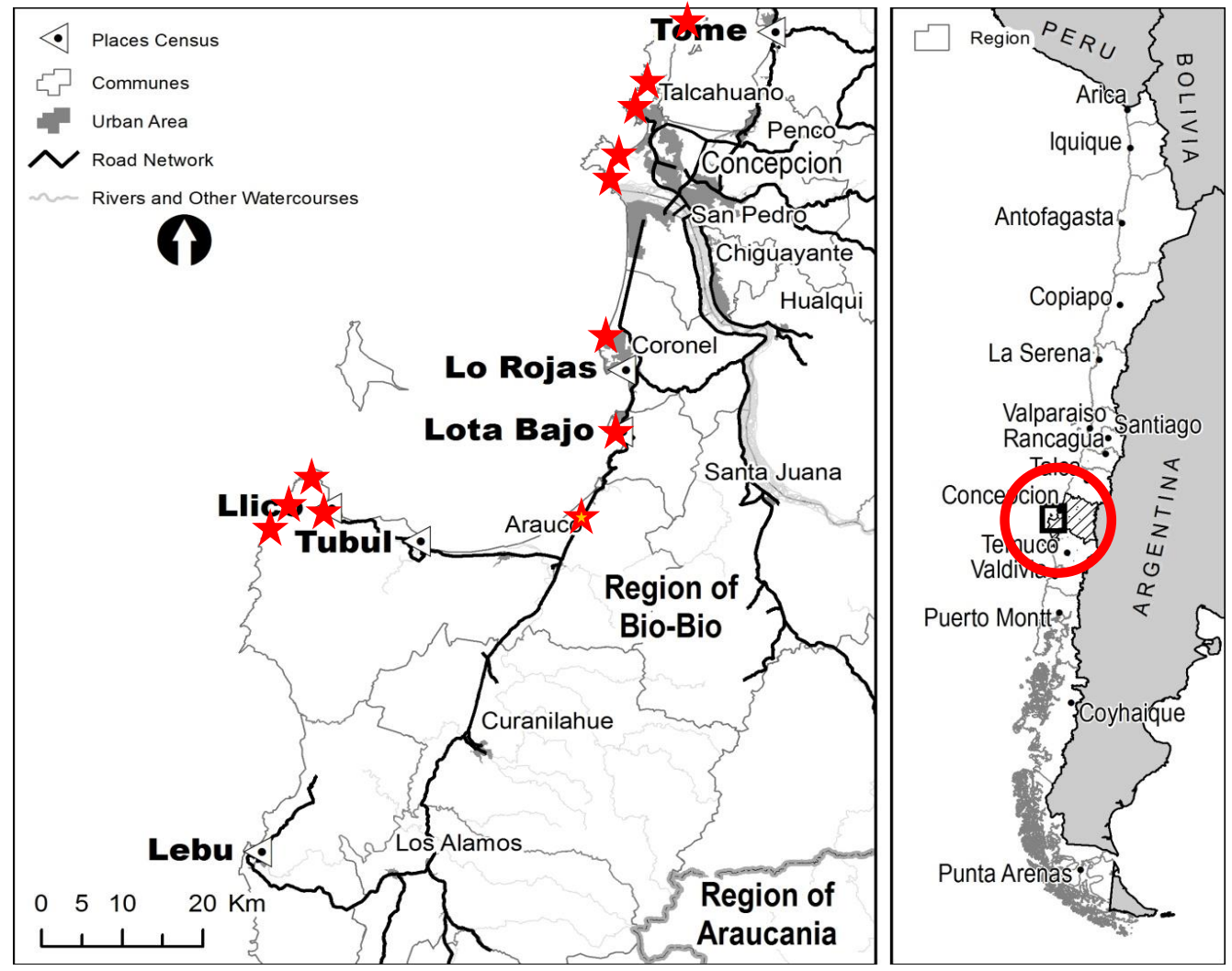




\section{Instructions}

\subsection{Instructions-English version}

\section{$\langle$ Slide 1>}

Welcome and thank you for agreeing to participate!!

$<$ Introduce yourself and your assistants.>

Today's decision-making exercise will take no more than 3hours to complete. At the end of the exercise, you will be paid in cash. You have already earned $\$ 2500$ for agreeing to participate. That money is yours to keep. You will now be given an opportunity to earn more money.

\section{$<$ Slide 2>}

Before we explain the instructions, we have a few simple rules:

- Please make sure you turn off all cell phones, pagers, etc. 〈pause>

- Please do not talk with any other participants during the exercise.

- If you have a question, please raise your hand.

- If you fail to follow these instructions, you will be asked to leave and forfeit any money earned.

- We hope that you are able to remain until the exercise ends. However, if you must leave before the exercise ends, you may keep the $\$ 2500$ for showing-up, but you will forfeit any additional money earned.

Any money you earn today and any decisions you make will be private. We will never tell anyone else in the exercise or outside of the exercise how much you've earned or what you decided in the exercise. In order to keep your information private please do not talk about your earnings or decisions with another participant.

You may have heard about this exercise from someone else. Although some parts may be similar to what other people have done, there may also be some differences. The instructions are very important as they explain the details of the exercise. Please pay careful attention to the instructions.

$<$ Slide 3>

Context: Today's exercise is based on a loco fishery. Many aspects will be similar to your Management Area. Some parts will be different, but that is ok, it is part of the exercise.

Rounds: You will be asked to make the same type of decisions many times in this exercise. You can think of these repeated decisions as years or seasons. This exercise will last at most 10 rounds.

\section{$<$ Slide 4>}

Groups: The 12 (6) participants in the room today have been randomly divided into 2 (1) separate groups of 6 people using the Participant ID Cards that you selected. 
In each group of 6 , the 3 people with yellow cards will be called the Yellow Participants, and 3 people with blue cards will be called the Blue Participants. The participant ID card shows your Group Number, participant Number, and whether you will be a Yellow or a Blue Participant.

\section{$<$ Slide 5>}

Resource: On the board, there are two zones (yellow and blue). Each magnet represents 1 loco. The blue zone starts with 70 blue locos, and the yellow zone starts with 45 yellow locos. Each round, you will decide how many locos to harvest. The 3 blue participants have the right to harvest blue locos, and the 3 yellow participants have the right to harvest yellow locos. Each person can harvest at most 5 locos each round. You do not have to harvest all 5 locos. You may harvest 0 or 1 or 2 or 3 or 4 or 5 . It is up to you to decide how many locos to harvest.

<slide 6>

Loco price: You will be paid $\$ 500$ in cash for each loco you harvest.

Growth of loco quantity: As you know, locos reproduce. We represent this in the exercise. After everyone has decided how many locos to harvest, we will remove the locos from the board and announce how many locos are left. The units of the loco resource that are left on the board will reproduce according to the following rule:

- For every 10 locos that are left on the board, we will add 1 more loco.

- There can never be more than 70 blue locos or 45 yellow locos.

Here are some examples: <actually remove the magnets from the board>

- <slide 7>If the total harvest of blue locos is 9, that leaves 61 locos at the end of the round. <slide 8>At the start of the next round, we will add back 6 locos, which means the new round begins with 67 . Are there any questions?

- <slide 9>If the total harvest of blue locos is 4, that leaves 66 blue locos at the end of the round. <slide 10>At the start of the next round, we cannot add back all 6 locos because that would be more than $70<$ show on the board>. Instead, we will add 4 so the new round begins with 70. slide 11 Are there any questions?

- The yellow zone works the same way, except that the limit is 45 .

<slide 12>

Fishery closure: In order for the blue loco fishery to remain open, there has to be at least 30 blue locos left on the board. At the end of the round, if there are fewer than 30 blue locos, then the blue zone will be closed for the rest of the exercise. The blue zone will not reopen. <slide 13>Similarly, if there are fewer than 15 yellow locos remaining in the yellow zone, then the yellow zone is closed and will not reopen. It is possible for one zone to be open while the other is closed.

Initial cash: Since the yellow zone is smaller, the yellow participants will start the exercise with 5000 pesos.

<slide 14>

Communication: At the start of each round, the blue participants will have 3 minutes to talk with each other. They may discuss any aspect of the exercise. They cannot use foul language, threaten 
other participants or make promises of side-payments. The 3 yellow participants must sit quietly and wait.

$<$ slide 15>

<if poaching > Harvesting from the other zone: Although the blue locos belong to the blue participants, it is possible for yellow participants to harvest blue locos. Blue participants cannot harvest yellow locos.

<slide 16>

<if monitoring > Authority monitoring: There is a chance that the authorities will patrol the blue zone. There is also a chance that the authorities will not patrol the blue zone. If a yellow participant is caught harvesting blue locos, then the person must pay a fine of $\$ 2000$ for each blue loco harvested.

<slide 17> Here's how it will work. First, we will roll this custom green 6-sided dice to determine whether the authorities will inspect one yellow participant. Two sides have the words "Yes inspection" and four sides have "No inspection." < slide 18> If we roll "Yes inspection," then one yellow participant will be inspected. If we roll "No inspection," then the authorities will not inspect anyone. <let the participants inspect the dice>

<slide 19> To determine who will be inspected, we will roll this custom red six-sided dice. Each yellow participant number, 4-5-6, is on two of the sides. The numbers on the die match the number of the yellow participant who will be monitored. <let the participants inspect the dice>

Let's try some examples.<do multiple examples now $>$

$<$ slide 20>

Local monitoring: (<if combined > In addition,) The blue participants can patrol the blue zone. If a yellow participant is caught harvesting blue locos, then that person must pay a fine of $\$ 2000$ for each blue loco harvested. IIf combined > If a yellow participant is inspected by both the authorities and the blue participants, the person will pay a single fine of $\$ 2000$ for each blue loco. The person will not be fined twice.

<slide 21>The blue participants will need to decide how much they want to spend on patrolling the blue zone. Here's how it will work. We will roll this white6-sided die to determine whether a yellow participant will be inspected.

Each blue participant can purchase sides of the dice to determine whether one yellow participant is inspected. Each side costs the buyer $\$ 250$. The more sides that the blue participants buy, the more likely it is that a yellow participant will be inspected. Each blue participant can purchase 0 or 1 or 2 sides of the dice.

$<$ slide 22>For example, if the blue participants purchase a combined total of 3 sides (at a cost of \$750), then the numbers 1-2-3 mean one yellow participant will be inspected, <slide 23> and 4-5-6 means that no one will be inspected.

$<$ slide 24>

If someone will be inspected, then we need to decide who that person will be. To determine who will be inspected, we will roll this custom red six-sided dice. Each yellow participant number, 4-5-6, is on two of the sides. The numbers on the dice match the number of 
the yellow participant who will be monitored. <let the participants inspect the dice $>$ Let's try some examples. <do multiple examples now>

Decision Card: Each person has a stack of Decision Cards, one card for each round. At the start of each round, use this card to record your decision about how many locos you will harvest. <if local monitoring > The blue participants will also indicate how much patrolling they will purchase. We will collect the Decision Cards and announce the results.

Record Sheet: Use the Record Sheet to keep track of your decisions and earnings each round. When you submit your decisions, also write your decisions on the Record Sheet.

Summary:

- You have to decide how many locos to harvest. You can harvest up to 5 locos in each round.

- You will receive $\$ 500$ for every loco you harvest.

- At the start of each round, 1 loco will be added for each 10 locos on the board, up to a limit of 70 in the blue zone and 45 in the yellow zone.

- <if poaching>Although the blue locos belong to the blue participants, it is possible for yellow participants to harvest blue locos.

- If there are less than 30 blue locos, then the blue zone will be closed for the rest of the exercise. If there are fewer than 15 yellow locos, then the yellow zone will be closed for the rest of the exercise.

- The blue participants can organize and talk with each other. The yellow participants are not organized and cannot talk.

- At the end of each round, we will announce all the results before proceeding to the next round.

- There will be at most 10 rounds. The exercise may end before that if both zones are closed.

- <If authority monitoring> There is a chance that the authorities will inspect the yellow participants to see if they harvested blue locos. If they catch a yellow participant with blue locos, then the person must pay a fine of $\$ 2000$ for each blue loco.

- $\quad$ If local monitoring>The blue participants can pay to patrol the blue zone. If they catch a yellow participant with blue locos, then the person must pay a fine of $\$ 2000$ for each blue loco.

- <additional if local and authority monitoring> If a yellow participant is caught by both the authorities and the blue participants, the person must pay a single fine of $\$ 2000$ for each blue loco.

We will start with two practice rounds. These practice rounds will not count for your earnings. Is everyone ready to begin the practice round?<pause $>$

And remember, now that we have started, please do not talk to anyone. If you have a question, please raise your hand and an assistant will come to you and help you. 


\subsection{Instructions-Spanish version}

\section{$\langle$ Diapo 1>}

Bienvenidos y gracias por aceptar participar en esta actividad!!

<Preséntese Usted y sus asistentes>

El ejercicio de toma de decisiones que realizaremos el día de hoy no tomará más de 3 horas en ser completado. Al final del ejercicio, se le pagará en dinero en efectivo. Usted ha ganado $\$$ 2.500 por aceptar participar. Ese dinero es para usted. Le daremos ahora una oportunidad de ganar más dinero.

\section{<Diapo 2>}

Antes de explicar las instrucciones, tenemos algunas reglas simples:

- Por favor asegúrese de apagar su teléfono celular, y otros aparatos electrónicos $\langle$ pausa

- Por favor, no hable con ningún otro participante durante el ejercicio.

- Si usted tiene una pregunta, por favor levante la mano.

- Si usted no sigue las instrucciones, le pediremos que se retire y podría perder el dinero ganado.

- Esperamos que pueda quedarse hasta que el ejercicio concluya. Sin embargo, si Usted debe retirarse antes que el ejercicio concluya, Usted puede mantener los $\$ 2.500$ por haberse presentado el día de hoy, pero perderá cualquier monto de dinero adicional que haya ganado.

Cualquier monto de dinero ganado hoy así como cualquier decisión que tome serán privadas. Nosotros nunca revelaremos a otros participantes en este ejercicio o fuera del ejercicio cuánto ganó o qué decisiones tomó durante el ejercicio. Con el propósito de mantener la información en privado por favor no hable con otros participantes respecto a sus ganancias o decisiones.

Usted puede haber escuchado sobre este ejercicio de parte de alguna persona. Aunque alguna parte de este ejercicio puede ser similar a lo que han hecho otras personas, podrían existir también algunas diferencias. Las instrucciones son muy importantes porque explican los detalles del ejercicio. Por favor, ponga cuidadosa atención a las instrucciones.

\section{$<$ Diapo 3>}

Contexto: El ejercicio de hoy está basado en la pesquería del Loco. Muchos aspectos serán similares a su propia Área de Manejo. Algunas partes serán diferentes, pero está bien, es parte del ejercicio.

$\underline{\text { Rondas: }}$ Le pediremos tomar el mismo tipo de decisiones varias veces en este ejercicio. Usted puede pensar en estas decisiones repetidas como años o temporadas. Este ejercicio durará máximo 10 rondas.

\section{<Diapo 4>}


Grupos: Los 12 (6) participantes que están hoy en la habitación han sido divididos aleatoriamente en 2 (1) grupos separados de 6 personas usando las tarjetas de identificación de participantes que Usted seleccionó.

En cada grupo de 6, las 3 personas con tarjetas amarillas serán llamadas Participantes Amarillos, y las 3 personas con tarjetas azules serán llamadas Participantes Azules. La tarjeta de identificación del participante muestra el Número de su Grupo, su Número de Participante, y si Usted será un participante Amarillo o Azul.

\section{$\langle$ Diapo 5>}

Recurso: En la pizarra se presentan dos zonas (amarilla y azul). Cada magneto representa 1 loco. La zona azul comienza con 70 locos azules, y la zona amarilla comienza con 45 locos amarillos. En cada ronda, usted decidirá cuántos locos extraer. Los 3 participantes azules tienen el derecho a extraer locos azules, y los 3 participantes amarillos tienen el derecho a extraer locos amarillos. Cada persona puede extraer como máximo un total de 5 locos por ronda. Usted no está obligado a extraer los 5 locos. Usted podría extraer 0 ó 1 ó 2 ó 3 ó 4 ó 5 . Es su decisión cuántos locos extraer.

\section{<Diapo 6>}

Precio del loco: A usted se le pagará \$ 500 en dinero efectivo por cada loco que extraiga.

Crecimiento de la cantidad de locos: Como Usted sabe, los locos se reproducen. Representamos esto en el ejercicio. Después de que todos hayan decidido cuántos locos extraer, sacaremos los locos desde la pizarra y anunciaremos la cantidad de locos que quedaron. Las unidades del recurso loco que queden en la pizarra se reproducirán de acuerdo a la siguiente regla:

- Por cada 10 locos que queden en la pizarra, nosotros agregaremos 1 loco.

- No podrá haber nunca más de 70 locos azules o 45 locos amarillos.

Aquí hay algunos ejemplos: <remover realmente los magnetos desde la pizarra>

- $\quad$ Diapo 7> Si la extracción total de locos azules es 9, eso deja 61 locos al final de la ronda. <Diapo $8>\mathrm{Al}$ inicio de la siguiente ronda agregaremos 6 locos, lo cual significa que la nueva ronda se inicia con 67 locos. ¿Alguna pregunta?

- <Diapo 9> Si la extracción total de locos azules es 4, eso deja 66 locos azules al final de la ronda. <Diapo 10> Al inicio de la segunda ronda no podemos agregar 6 locos porque eso implicaría tener más de $70<$ mostrar en la pizarra>. En su lugar, agregaremos 4 para que la nueva ronda comience con 70. Diapo 11 ¿Hay alguna pregunta?

- La zona amarilla funciona de la misma forma, excepto que el límite es 45 .

\section{$<$ Diapo 12>}

Cierre de la pesquería: Para que la pesquería de los locos azules se mantenga abierta, deben quedar a lo menos 30 locos azules en la pizarra. Si al final de una ronda hay menos de 30 locos azules, entonces la zona azul será cerrada por el resto del ejercicio. La zona azul no será reabierta. <Diapo 13> Igualmente, si quedan menos de 15 locos amarillos en la zona amarilla, entonces la zona amarilla será cerrada y no será reabierta. Es posible que una zona esté abierta mientras la otra está cerrada. 
Dinero en efectivo inicial: Debido a que la zona amarilla es más pequeña, los participantes amarillos iniciarán el ejercicio con 5.000 pesos.

\section{<Diapo 14>}

Comunicación: Al inicio de cada ronda, los participantes azules tendrán 3 minutos para hablar entre ellos. Ellos pueden discutir cualquier aspecto del ejercicio. Ellos no pueden utilizar lenguaje inapropiado, amenazar al resto de los participantes, ni tampoco hacer promesas de pagos laterales. Los 3 participantes amarillos deben estar sentados en silencio y esperar.

\section{$<$ Diapo 15>}

Ssi hay extracción furtiva> Extracción desde la otra zona: Aunque los locos azules pertenecen a las participantes azules, es posible para los participantes amarillos extraer locos azules. Los participantes azules no pueden extraer locos amarillos.

\section{$<$ Diapo 16>}

$\leq$ con vigilancia > Vigilancia de las autoridades: Hay una posibilidad de que las autoridades patrullen la zona azul. También hay una posibilidad de que las autoridades no patrullen la zona azul. Si un participante amarillo es descubierto extrayendo locos azules, entonces esta persona tendrá que pagar una multa de \$2.000 por cada loco azul extraído.

<Diapo 17>Así es como esto funcionará. Primero, lanzaremos este dado personalizado verde de 6 lados para determinar si las autoridades inspeccionarán a un participante amarillo. Dos lados del dado tienen las palabras "Sí inspección" y cuatro lados tienen "No inspección". <Diapo 18>Si resulta "Sí inspección", un participante amarillo será inspeccionado. Si resulta "No inspección", entonces las autoridades no inspeccionarán a nadie. <dejar que los participantes inspecciones el dado>.

<diapo 19> Para determinar quién será inspeccionado, tiraremos este dado rojo personalizado de 6 lados. El número de cada participante amarillo, 4-5-6, está en dos lados. Los números en el dado corresponden al número del participante amarillo que será inspeccionado. $<$ dejar que los participantes inspecciones el dado>.

Hagamos algunos ejemplos.

$<$ hacer múltiples ejemplos ahora>

\section{$<$ Diapo 20>}

Vigilancia local: <si se usa combinada> Adicionalmente,) Los participantes azules pueden patrullar la zona azul. Si un participante amarillo es detectado extrayendo locos azules, entonces esta persona debe pagar una multa de \$2.000 por cada loco azul extraído. <Si es combinado $\rangle \mathrm{Si}$ un participante amarillo es inspeccionado por ambos, la autoridad y los participantes azules, la persona pagará una única multa de \$2.000 por cada loco azul. La persona no será multada dos veces.

<Diapo 21> Los participantes azules deberán decidir cuánto desean gastar en patrullaje de la zona azul. Así es como esto funcionará. Tiraremos un dado blanco de seis lados para determinar si un participante amarillo será inspeccionado. 
Cada participante azul puede comprar lados del dado para determinar si un participante amarillo es inspeccionado. Cada lado cuesta al comprador \$250. Mientras más lados sean comprados por los participantes azules, es más probable que un participante amarillo sea inspeccionado. Cada participante azul puede comprar 0 ó 1 ó 2 lados del dado.

<Diapo 22> Por ejemplo, si los participantes azules compran de manera combinada un total de 3 lados (a un costo total de \$750), entonces los números 1-2-3 significan que un participante amarillo será inspeccionado, 〈Diapo 23> y 4-5-6 significan que nadie será inspeccionado.

<Diapo 24> Si alguien llegara a ser inspeccionado, entonces nosotros necesitaremos decidir quién será esa persona. Para determinar quién será inspeccionado, lanzaremos otro dado de 6 caras. Si resulta 1 ó 2, el participante 4 será inspeccionado. Si resulta 3 ó 4, entonces el participante 5 será inspeccionado. Y si resulta 5 ó 6 , entonces el participante 6 será inspeccionado. Probemos con algunos ejemplos. <hacer múltiples ejemplos ahora>

$\mathrm{Si}$ alguien es inspeccionado, entonces nosotros necesitaremos decidir quién será esa persona. Para determinar quién será inspeccionado, lanzaremos este dado personalizado rojo de 6 caras. El número de cada participante amarillo, 4-5-6, está en dos de los lados. Los números en el dado corresponden al número del participante amarillo que será inspeccionado. <dejar que los participantes inspecciones el dado>. Probemos algunos ejemplos. <hacer mútiples ejemplos ahora>

Tarjeta de decisión: Cada persona tiene un conjunto de Tarjetas de Decisión, una tarjeta por cada ronda. Al inicio de cada ronda, utilice esta tarjeta para registrar su decisión respecto a cuántos locos usted extraerá. <Si existe vigilancia local > Los participantes azules también indicarán cuanto patrullaje ellos comprarán. Nosotros recolectaremos las tarjetas de decisión y anunciaremos los resultados.

Hoja de Registro: Utilice la Hoja de Registro para llevar la cuenta de sus decisiones y ganancias en cada ronda. Cuando entregue sus decisiones, escríbalas también en la Hoja de Registro.

\section{Resumen:}

- Usted debe decidir cuántos locos extraer. Usted puede extraer hasta un máximo de 5 locos en cada ronda.

- Usted recibirá $\$ 500$ por cada loco que usted extraiga.

- Al inicio de cada ronda, 1 loco se agregará por cada 10 locos que permanezcan en la pizarra, hasta un límite de 70 en la zona azul y 45 en la zona amarilla.

- <si extracción furtiva> Aun cuando los locos azules pertenecen a los participantes azules, es posible para los participantes amarillos extraer locos azules.

- Si hay menos de 30 locos azules, entonces la zona azul será cerrada por el resto del ejercicio. Si hay menos de 15 locos amarillos, entones la zona amarilla será cerrada por el resto del ejercicio.

- Los participantes azules se pueden organizar y hablar entre ellos. Los participantes amarillos no están organizados y no pueden hablar.

- Al final de cada ronda, nosotros vamos a anunciar todos los resultados antes de proceder a la siguiente ronda.

- Existirá un máximo de 10 rondas. El ejercicio podría terminar antes de aquello si ambas zonas están cerradas. 
- $\quad$ Si vigilancia de las autoridades> Hay una posibilidad que las autoridades inspeccionen a los participantes amarillos para ver si ellos han extraído locos azules. Si ellos descubren a un participante amarillo con locos azules, entonces la persona debe pagar una multa de $\$ 2.000$ por cada loco azul.

- $\quad$ Si vigilancia local> Los participantes azules pueden pagar para patrullar la zona azul. Si ellos sorprenden a un participante amarillo con locos azules, entonces la persona debe pagar una multa de $\$ 2.000$ por cada loco azul.

- <adicional si existe vigilancia local y de las autoridades>. Si un participante amarillo es sorprendido por ambos, las autoridades y los participantes azules, la persona debe pagar una única multa de $\$ 2.000$ por cada loco azul.

Nosotros vamos a empezar con dos rondas de práctica. Estas rondas de práctica no serán contabilizadas en sus ganancias. ¿Están todos listos para empezar las rondas de práctica? $<$ pausa $>$

Y recuerden, ahora que hemos empezado, por favor no hablen con nadie. Si usted tiene una pregunta, por favor levante su mano y un asistente irá hasta usted y le ayudará. 


\section{Investment in Local Monitoring}

Table A-4.1. Individual probability of investing in local monitoring (probit)

TURF members

T5. Both

Initial Biomass - Blue

Initial Biomass - Yellow

Demographics

Male

Age (years)

Years of formal

schooling

Constant

\# Observations
(1)

(2)

Students

$$
-0.78
$$

(0.66)

0.06

(0.11)

$-0.01$

(0.06)

(0.02)

0.19

(0.89)

0.20 **

0.01

(0.10)

0.01

(0.05)

0.05

$-0.06$

(0.10)

(0.10)

$-0.83$

$-2.09$

(1.33)

(4.82) 
Table A.4-2. Variance ratio test (TURF members)

\begin{tabular}{lcccccc}
\hline Group & Obs & Mean & Std. Err. & Std. Dev. & [95\% Conf. Interval] \\
\hline 4. Local & 21 & 0.73 & 0.10 & 0.48 & 0.51 & 0.95 \\
5. Both & 18 & 0.90 & 0.14 & 0.61 & 0.59 & 1.20 \\
Combined & 39 & 0.81 & 0.09 & 0.54 & 0.63 & 0.98 \\
\hline Test & $p$-value & & & & & \\
$\quad H_{a}: r<1$ & 0.1464 & & & & \\
$\quad H_{a}: r \neq 1$ & 0.2928 & & & & & \\
$\quad H_{a}: r>1$ & 0.8536 & & & & & \\
\hline
\end{tabular}

$H_{0}: r=1$, where $r=\mathrm{sd}($ Local $) / \mathrm{sd}($ Both)

Table A.4-3. Variance ratio test (Students)

\begin{tabular}{lcccccc}
\hline Group & Obs & Mean & Std. Err. & Std. Dev. & [95\% Conf. Interval] \\
\hline 4. Local & 21 & 1.16 & 0.05 & 0.22 & 1.06 & 1.26 \\
5. Both & 21 & 1.01 & 0.06 & 0.28 & 0.88 & 1.14 \\
Combined & 42 & 1.08 & 0.04 & 0.26 & 1.00 & 1.16 \\
\hline Test & p-value & & & & & \\
$\quad H_{a}: r<1$ & 0.1100 & & & & \\
$\quad H_{a}: r \neq 1$ & 0.2200 & & & & & \\
$\quad H_{a}: r>1$ & 0.8900 & & & & & \\
\hline
\end{tabular}

$H_{0}: r=1$, where $r=\mathrm{sd}($ Local $) / \mathrm{sd}($ Both $)$ 